\title{
Environmental Forcing of Red Tides in the Southern Benguela
}

\author{
Mark R. Jury ${ }^{1,2}$ \\ ${ }^{1}$ University of Zululand, KwaDlangezwa 3886, South Africa \\ ${ }^{2}$ Physics Department, University of Puerto Rico, Mayagüez, PR 00681, USA
}

Correspondence should be addressed to Mark R. Jury; mark.jury@upr.edu

Received 18 February 2014; Revised 10 April 2014; Accepted 24 April 2014; Published 16 June 2014

Academic Editor: Robert Frouin

Copyright (c) 2014 Mark R. Jury. This is an open access article distributed under the Creative Commons Attribution License, which permits unrestricted use, distribution, and reproduction in any medium, provided the original work is properly cited.

\begin{abstract}
The Southern Benguela cape upwelling plumes have inshore wind shadows prone to red tides in late summer. Their intensity and coverage are estimated by satellite fluorescence measurements in the period 1997-2012 and qualified by in situ reports. High satellite fluorescence cases are identified at daily to seasonal time scales, and characteristics of the upper ocean and lower atmosphere are studied using third generation reanalyses. A dominant feature is easterly winds over the Cape Peninsula $\left(34^{\circ} \mathrm{S}, 18^{\circ} \mathrm{E}\right)$ induced by a ridging anticyclone-coastal low weather pattern. Over Cape Columbine $\left(33^{\circ} \mathrm{S}\right)$, there is a wind shadow with cyclonic wind and current shear. Composite atmospheric profiles reveal a $4^{\circ} \mathrm{C}$ temperature inversion near $500 \mathrm{~m}$ that traps a coastal wind jet $>6 \mathrm{~m} / \mathrm{s}$ below $200 \mathrm{~m}$. The composite shelf oceanography shows a relic upwelling plume below $10 \mathrm{~m}$ overtopped by warmer water near the coast, providing the thermal stratification needed for biotic aggregation. Data from the IPSL5 coupled climate model over the period 1980-2080 indicates that environmental conditions favoring red tides may become more frequent.
\end{abstract}

\section{Introduction}

The Southern Benguela $\left(31.5-34^{\circ} \mathrm{S}, 17.5-18.5^{\circ} \mathrm{E}\right)$ is a zone of summer upwelling and equatorward flow [1-4]. The upwelling intensifies next to two capes at $34^{\circ} \mathrm{S}$ and $33^{\circ} \mathrm{S}$ [4-7]. In the north of each cape, there is wind shadow and corresponding band of warm surface water $[8,9]$. Cyclonic wind shear produces a clockwise circulation in the leeward bay [9-12] where high chlorophyll content promotes dinoflagellate blooms or "red tides" [13]. In situ surveys have found that red tides form in $\sim 5 \times 20 \mathrm{~km}$ patches and accumulate over a few days [14-16], mainly in February to April season.

The upwelling is pulsed by passing weather systems and amplified by coastal low pressure cells [17-19]. As they transit the Southern Benguela, equatorward flow becomes shallow and sheared by the topography. Wind shadow zones grow offshore and stratified conditions lasting many days contribute to red tides [20-24], which appear rapidly at high concentrations suggesting that local growth is boosted by confluent circulations $[16,25,26]$. The decay of red tides leads to low oxygen water and marine life mortalities with economic consequences [27].
Most red tides exhibit spectral radiance in the fluorescence band $\pm 683 \mathrm{~nm}$. These can be measured near the surface by satellite remote sensing $[28,29]$. The sea wide-field sensor (SeaWiFS) collected data from 1997 to 2010 in spectral bands from 412 to $865 \mathrm{~nm}$. Since 2002, the moderate resolution imaging spectroradiometer (MODIS) provides declouded 8day $9 \mathrm{~km}$ resolution imagery in $405-877 \mathrm{~nm}$ spectral bands that enable a fluorescence line height (FLH) calculation [30]. MODIS FLH is found to be consistent with in situ observations of red tide [31-33] as a radiometric index of relative harmful phytoplankton biomass. The European MERIS satellite also has spectral bands across the fluorescence peak capable of detecting red tides and cyanobacteria blooms [34], even in coastal turbid waters [35]. FLH is sensitive to phytoplankton nutrient status, growth rates, species, and size through variations in quantum yield. In addition to fluorescence proxies, satellite measured chlorophyll (CHL) indicates high biomass dinoflagellate blooms and sea surface temperature (SST) helps in establishing the background conditions that contribute to the formation of red tides during winddriven coastal upwelling relaxation. Satellite altimetry can 
resolve the background circulation in conjunction with ocean model assimilation of in situ observations.

Multiple environmental factors can be evaluated by regression of variables onto an FLH index. Additional FLH proxies may be generated from the National Aeronautics and Space Administration (NASA) ocean biogeochemical model (NOBM). The NOBM physical [36] and chemical submodels [37] assimilate satellite data in parallel with environmental observations. The model calculates budgets and interactions between phytoplankton, nutrients, minerals and zooplankton, and consequent dissolved organic material and detritus. The NOBM employs a sophisticated Kalman ensemble filter. Its use in the coastal zone is limited by a $100 \mathrm{~km}$ resolution, so application here is made in the broader upwelling zone north of Cape Columbine.

Ocean-atmosphere reanalysis products are employed here to study the environmental forcing of red tides in the Southern Benguela in February-April season in 1997-2012. This is a challenge given the coastal pulsed nature of upwelling [38-41]. The paper addresses the following research questions. What are the temporal and spatial characteristics of satellite fluorescence that indicate red tides? What are the environmental influences on red tides at event to seasonal time scales? Are conditions favoring red tides more likely in future?

Methods are employed to bring out the environmental forcing of red tides at time scales from daily local weather to interannual ocean influence. The spatial scale includes the two shelf zones leeward of the Cape Peninsula and Cape Columbine upwelling plumes, where red tides are most frequently observed. The study does not attempt to "predict" red tides but to understand the multivariate environmental forcing. Model fitting is done only to extend the MODIS record back to SeaWiFS and to establish a daily index corresponding with red tides.

\section{Data and Methods}

The primary index to estimate red tide intensity and coverage in the Southern Benguela is the MODIS fluorescence line height (FLH) $9 \mathrm{~km}$ 8-day data from July 2002 to December 2012 obtained from NASA. A SeaWiFS FLH proxy is calculated by multivariate regression of radiance data in the period of overlap with MODIS, extending the record back to September 1997. Time series are averaged over the Southern Benguela shelf zone: $34-31.5^{\circ} \mathrm{S}, 17.5-18.5^{\circ} \mathrm{E}$ (Figure $1(\mathrm{e})$ ), to indicate red tides within the two cape upwelling shadows. In situ red tide reports from the Fisheries Service (MCM) were used to qualify the satellite estimates, and cases were screened accordingly. In addition to FLH data, satellite chlorophyll $(\mathrm{CHL})$ is analyzed given its relationship to winds and currents in coastal upwelling zones $[42,43]$. A proxy for FLH at daily time scale is an arithmetic average of NOBM chlorophytes and cyanobacteria. For comparison with oceanographic sets, the SeaWiFS-MODIS FLH is binned into months. Thus, we have FLH or FLH proxies at three time scales (daily, 8-day, monthly) to investigate the shelf-scale environmental forcing
TABLE 1: FLH cases for inclusion in composites screened by in situ reports.

\begin{tabular}{lccc}
\hline High daily & High 8 days & High month & Low month \\
\hline 27 February 2000 & 29 March 2000 & April 2002 & February 1998 \\
7 March 2002 & 15 April 2000 & February 2006 & March 1998 \\
20 February 200518 February 2005 & March 2006 & February 1999 \\
18 March 2007 & 26 February 2005 & March 2007 & March 2001 \\
23 March 2008 & 21 March 2008 & April 2007 & February 2003 \\
21 April 2009 & 7 April 2009 & March 2008 & March 2003 \\
24 March 2012 & 29 March 2012 & April 2008 & April 2005 \\
\hline
\end{tabular}

of red tides in the period 1997-2012. FLH case studies (qualified by in situ reports) are listed in Table 1.

Global atmospheric and oceanography datasets with 30$50 \mathrm{~km}$ resolution are used to understand the shelf dynamics. Monthly wind stress, surface and upper wind, wind vorticity, sea level air pressure (SLP), surface temperature (Ts), latent heat flux (evaporation), specific humidity, and precipitable water are obtained from the coupled forecast system (hereafter, CFS [44]). Daily atmospheric data are obtained from the National Center for Environmental Prediction (NCEP) operational assimilation system and time- and space-averaged to match FLH for temporal analysis. Oceanographic fields are provided by Simple Ocean Data Assimilation version 2.1.6 (SODA, [45]) and include subsurface (1-100 m) temperature, salinity, currents and vertical motion, sea surface height, and European Community Medium-Range Weather Forecasts (ECMWF) wind stress. Monthly ocean data assimilation is performed within the Geophysical Fluid Dynamics Lab Modular Ocean Model version 4 [46]. Coastal upwelling and mesoscale winds are studied using daily $25 \mathrm{~km}$ NOAA SST data [47], $25 \mathrm{~km}$ J-OFURO reanalysis [48], satellite scatterometer measurements from QuikSCAT and ASCAT, and $4 \mathrm{~km}$ Meteosat infrared imagery. Atmospheric mixed layer profiles are studied by composite averaging of daily aircraft (AMDAR), radiosonde, and NCEP wind and temperature profiles near Cape Town Airport for high (daily) FLH cases. In general, data from "first generation" reanalyses (at $200 \mathrm{~km}$ resolution) are unsuitable for shelf-scale analysis and use here.

The environmental forcing of red tides is evaluated by multivariate regression of candidate predictors onto FLH in the form of (a) mean annual cycle, (b) monthly, (c) 8-day, and (d) daily data. This is done by backward stepwise removal of less influential variables, until an optimal multivariate algorithm is found. These time scales represent a progression from the "climate envelope" to the "local weather" which induces red tides in the coastal zone. Oceanographic and atmospheric structures are analyzed as depth or height sections over the Southern Benguela shelf $\left(34-31.5^{\circ} \mathrm{S}, 17^{\circ}-19^{\circ} \mathrm{E}\right)$, based on composites of the seven highest FLH months in February to April season minus the seven lowest FLH months (hereafter "high minus low"). Red tide events in the 8-day FLH record are studied by composite-averaging maps of SLP, SST, winds, latent heat flux, and MODIS FLH imagery. FLH index-to-field correlations are calculated for monthly surface 


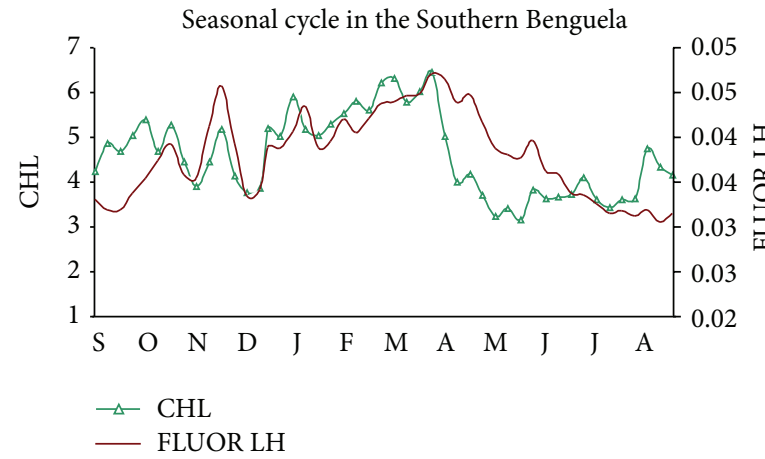

(a)

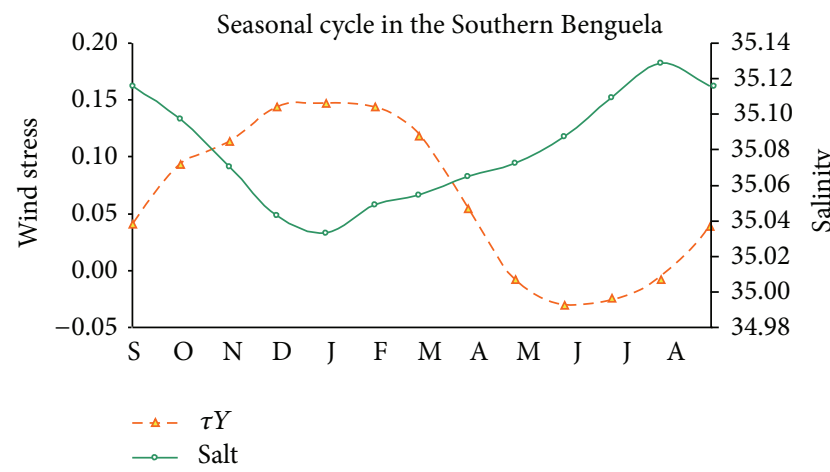

(c)

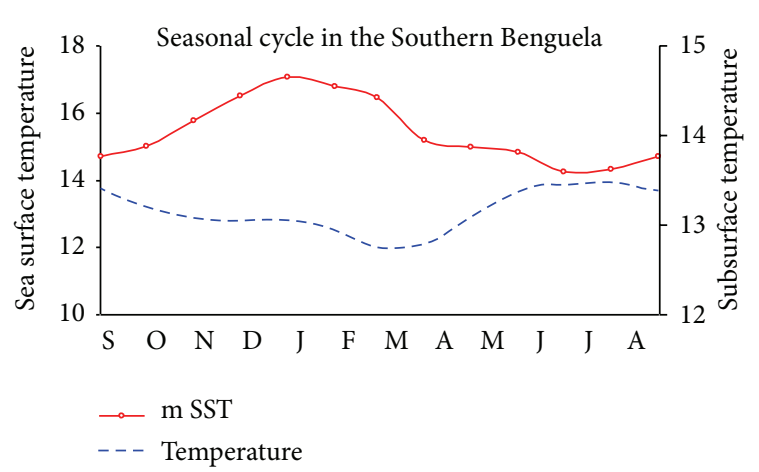

(b)

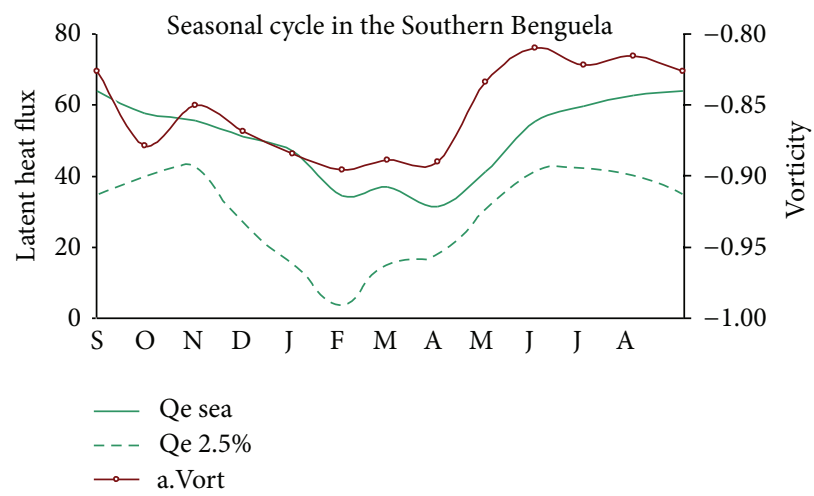

(d)

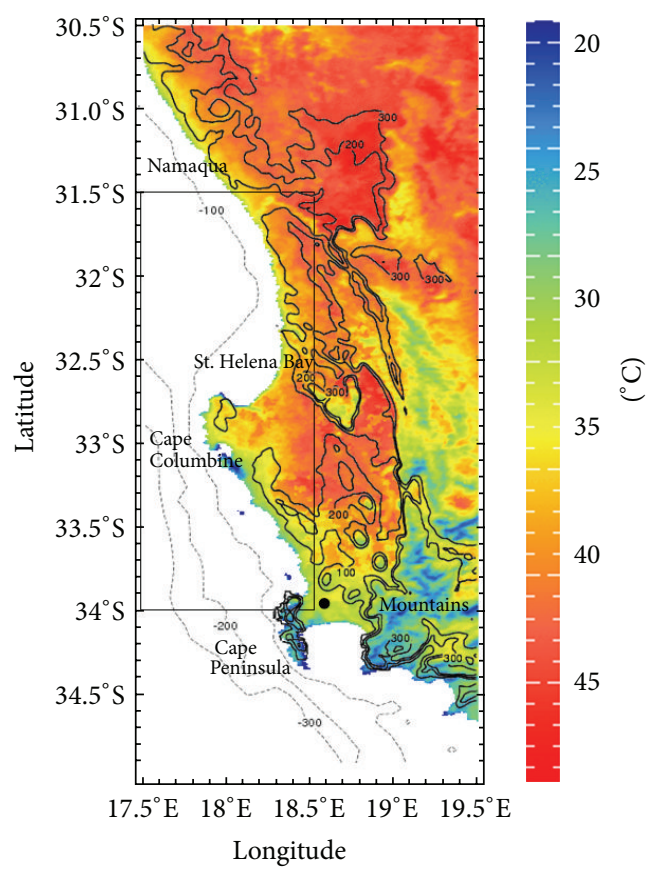

(e)

FIGURE 1: Mean annual cycle averaged over the Southern Benguela 1997-2012 for the following: (a) 8-day SeaWiFS-MODIS chlorophyll and fluorescence; (b) monthly MODIS SST and SODA 1-100 m temperature; (c) ECMWF meridional wind stress and SODA 1-100 m salinity; (d) coupled forecast system (CFS) air-sea latent heat flux and lowest $2.5 \%$ absolute vorticity $\times 10^{-5} \mathrm{~s}^{-1}$; (e) day-time land surface temperatures for high (daily) FLH cases with coastal topography and place names. Box is the averaging area for all analyses: $34-31.5^{\circ} \mathrm{S}, 17.5-18.5^{\circ} \mathrm{E}$; dot is regional airport. 
temperature, wind stress, latent heat flux, meridional upper wind, and sea level air pressure both within and around the Southern Benguela in February to April season. Pairwise correlations are analyzed between FLH and monthly environmental variables averaged over $34-31.5^{\circ} \mathrm{S}, 17.5-18.5^{\circ} \mathrm{E}$, except the s-n SLP index: $10-20^{\circ} \mathrm{E}, 35-45^{\circ} \mathrm{S}$ minus $15-25^{\circ} \mathrm{S}$. Statistical significance is evaluated according to the degrees of freedom as limited by record length, temporal resolution/averaging, and persistence.

Given the peculiar sea level air pressure (SLP) pattern found in the FLH index-to-field correlations, data from the French Institut Pierre Simon Laplace (IPSL) version 5 coupled general circulation model used for climate change projections [49] is evaluated over the period 1980-2080. Principal component clusters are calculated for February to April SLP and air temperature $\left(T_{a}\right)$. The leading mode of the IPSL5 simulated SLP resembles the FLH correlation pattern, so its trend and variance are analyzed. The IPSL5 is selected from a long list of models in the Intergovernmental Panel on Climate Change (IPCC) Intercomparison Project (CMIP5) because it exhibits low differences between simulated and observed conditions in the Benguela upwelling zone [50]. The IPSL5 model is described by Dufresne et al. [51] and has a dynamic coupling and feedback scheme that accurately simulates past climate. Its horizontal resolution is $\sim 100 \mathrm{~km}$ and representative of large scale environmental forcing, but not shelf-or event-scale processes.

\section{Results}

3.1. Annual Cycle. The mean annual cycle is studied based on red tide index area-averaged 8-day FLH and CHL values (Figure 1(a)). Both variables show a gradual rising trend from December to April, following an initial surge in November. CHL drops precipitously in April while FLH remains high then. Both annual cycles bottom out in July as coastal upwelling declines. It can be noted that river inflows are near zero from January to April, and thus "mistaken" turbidity events are unlikely. The annual cycle of SST is at a maximum in January while subsurface temperatures are at a minimum in March (Figure 1(b)). The larger difference represents stratification $d T / d z$ necessary for biotic aggregation. Subsurface salinity is inversely related to SST with a minimum in January and a maximum in July. Meridional wind stress has a large annual cycle with equatorward values peaking from December to February, then falling rapidly in March to negative values in June (Figure 1(c)). Latent heat flux is a minimum over the shelf from February to April, and its lowest $2.5 \%$ of cases falls almost to zero in February. Similarly wind vorticity is most cyclonic from February to April, when standing clockwise rotors prevail over the coast. Wind vorticity rises rapidly (anticyclonic) after May (Figure 1(d)) to inhibit upwelling and red tides. Figure 1(e) provides a map view of the Southern Benguela and its topography. Day-time land surface temperatures in high (daily) FLH cases exhibit values $>40^{\circ} \mathrm{C}$ in wind shadow zones. Pairwise correlations of environmental variables with the annual cycle of FLH (Table 2) are high for latent heat flux (-0.95),
TABLE 2: Pairwise cross-correlations of monthly data.

\begin{tabular}{lccc}
\hline Annual & FLH & Anomaly & FLH \\
\hline Algae & 0.38 & Algae & 0.12 \\
Phyto & 0.40 & Phyto & 0.11 \\
MLD & $-\mathbf{0 . 8 8}$ & MLD & -0.03 \\
V curr & 0.35 & V curr & 0.07 \\
U curr & -0.42 & U curr & -0.04 \\
W-50 & 0.14 & W-50 & 0.17 \\
Temp & $-\mathbf{0 . 9 2}$ & Temp & -0.06 \\
Salt & $-\mathbf{0 . 8 0}$ & Salt & 0.02 \\
SSH & -0.13 & SSH & -0.09 \\
tau $X$ & -0.71 & tau $X$ ec & $-\mathbf{0 . 3 9}$ \\
tau $Y$ & 0.41 & tau $Y$ ec & 0.27 \\
dST/dz & 0.71 & dST/dz & -0.23 \\
m SST & 0.59 & m SST & -0.27 \\
oi SST & 0.62 & oi SST & $-\mathbf{0 . 3 5}$ \\
Vort. & -0.69 & Vort. & -0.24 \\
Qe sea & $-\mathbf{0 . 9 5}$ & Tair & 0.16 \\
Qe 2.5\% & -0.74 & S salt & 0.16 \\
& & tau $X$ cf & $-\mathbf{0 . 3 8}$ \\
\multicolumn{1}{c}{$90 \%$ confidence (bold) } & tau $Y$ cf & $\mathbf{0 . 3 3}$ \\
$\quad|\mathrm{r}|>0.80$ annual cycle & W 700 & 0.10 \\
$|\mathrm{r}|>0.30$ anomaly series & Qe sea & -0.28 \\
\hline
\end{tabular}

TABLE 3: Multiple regression statistics: mean annual cycle of monthly FLH.

\begin{tabular}{lcccc}
\hline Adj. $R$ sq. & 0.974 & & & \\
Std. error & 0.001 & & & \\
Obs. & 12.0 & & & \\
\hline ANOVA & df & SS & MS & $F$ \\
\hline Regression & 3.0 & 0.000 & 0.000 & 138.2 \\
Residual & 8.0 & 0.000 & 0.000 & \\
Total & $\mathbf{1 1 . 0}$ & $\mathbf{0 . 0 0 0}$ & & \\
\hline Variables & Coeff. & Std. error & $t$ stat & $P$ value \\
\hline Intercept & 2.666 & 0.434 & 6.1 & 0.000 \\
Temp. & -0.014 & 0.001 & -10.4 & 0.000 \\
Salt & -0.069 & 0.013 & -5.5 & 0.001 \\
tau $Y$ & -0.032 & 0.004 & -7.3 & 0.000 \\
\hline
\end{tabular}

subsurface temperature $(-0.92)$, and mixed layer depth $(-0.88)$. Multivariate regression onto the annual cycle of monthly FLH fits $97 \%$ of variance with negative coefficients for subsurface temperature and salinity and meridional wind stress (Table 3) with $\sim 3$ degrees of freedom.

3.2. Characteristics of High Fluorescence Spells. The environmental forcing of red tides in early 2002 is studied using daily FLH proxy and daily NCEP data. Multivariate regression (Table 4, Figure 2(a)) yields negative coefficients for $U$ wind (-1.06), $V$ wind $(-0.44)$, SST $(-0.49)$, south-north SLP $(-0.67)$, and mixed layer depth $(-0.79)$ and a positive coef- 

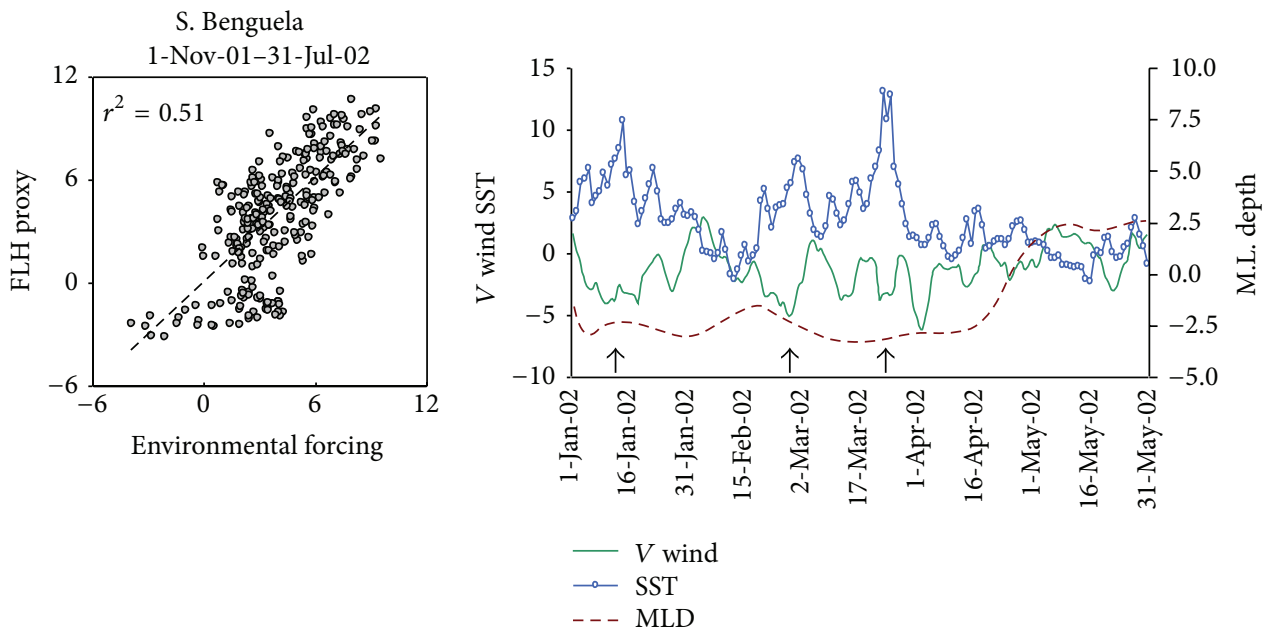

(a)

(b)

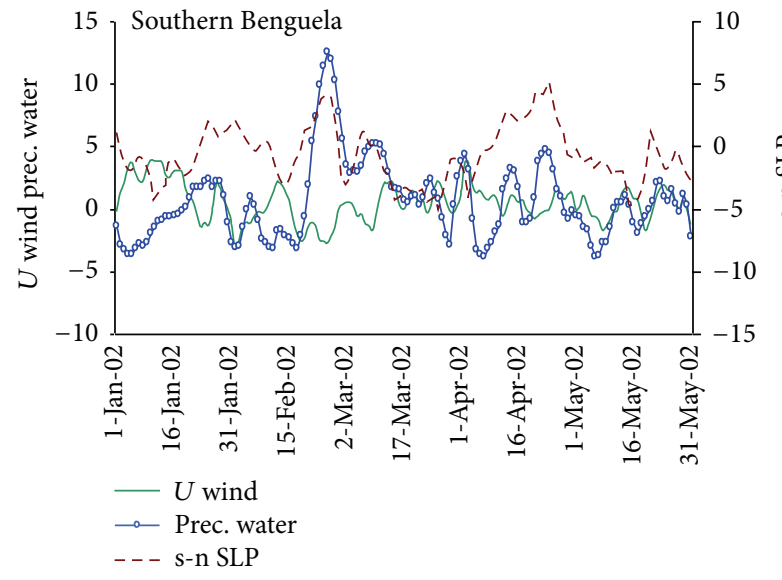

(c)

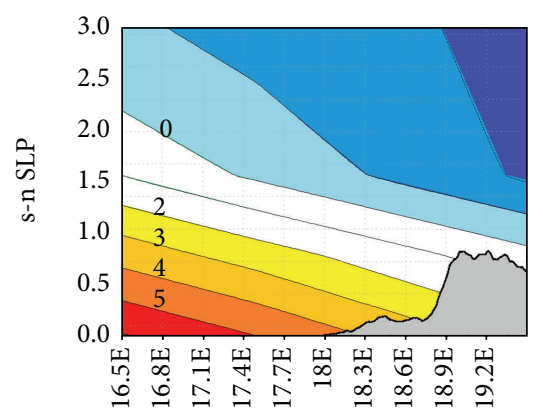

(d)

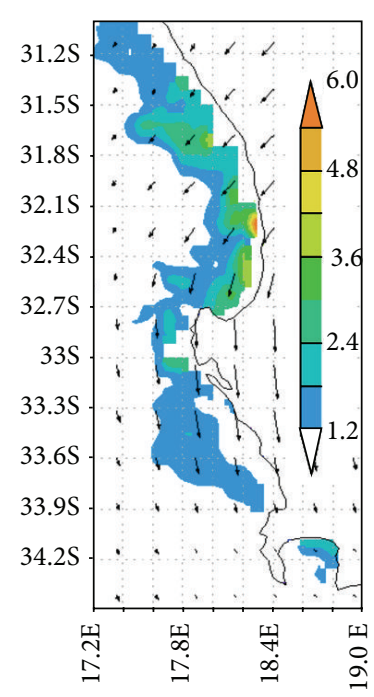

(e)

FIGURE 2: (a) Scatterplot of environmental model versus daily NOBM FLH proxy (cf. Table 4). (b) January to May 2002 time series of daily normalized departures of CFS meridional wind, NOAA SST, and NOBM mixed layer depth. (c) CFS zonal wind, precipitable water, and south minus north sea level air pressure index. (d) CFS meridional wind cross-section averaged $34-31.5^{\circ} \mathrm{S}$, Feb-Apr 2002, indicating depth of equatorward flow in $\mathrm{km}$. (e) SeaWiFS FLH proxy $\left(10^{-2}\right), 6-13$ March 2002, and ECMWF wind stress anomalies $($ March 2002, max = $0.08 \mathrm{Nm}^{-2}$ ). Arrows in (b) highlight upwelling relaxation.

ficient for atmospheric precipitable water $(+0.28)$. The multivariate environmental algorithm explains $52 \%$ of FLH variance (Table 4 ) with $>50$ degrees of freedom. Analyzing the normalized time series, frequent upwelling relaxations are noted (Figure 2(b)): SSTs peaked three times, meridional winds reversed, and the mixed layer was shallow. Zonal winds were persistently westward in February coincident with a positive s-n SLP index (Figure 2(c)) indicating a "ridged anticyclone-west coast trough" weather pattern. Precipitable water was high at the end of February 2002, due to an influx of tropical air. Meridional (equatorward) winds remained shallow during this period (Figure 2(d)) and thus sheared by the coastal topography. Wind stress anomalies along the coast were offshore and poleward, and satellite measured fluorescence was high in the shelf zone leeward of the two upwelling plumes (Figure 2(e)). Pitcher et al. [9] summarize in situ 


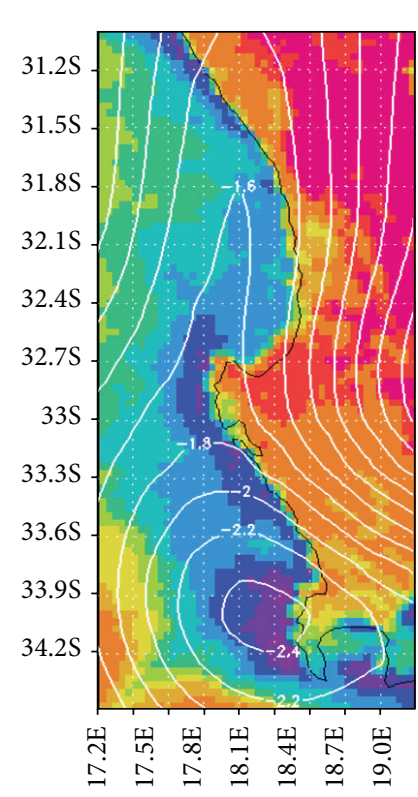

(a)

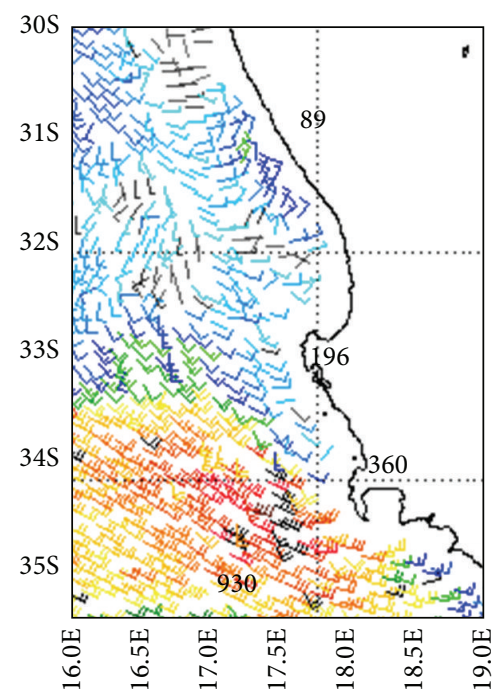

(c)
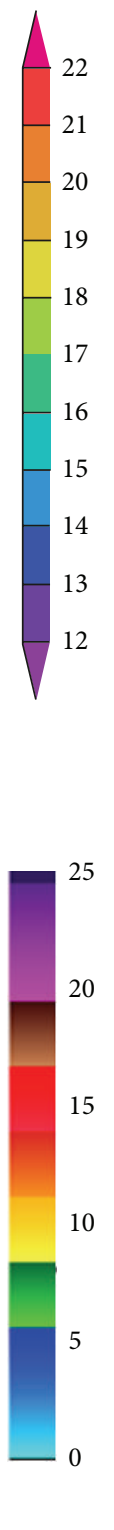

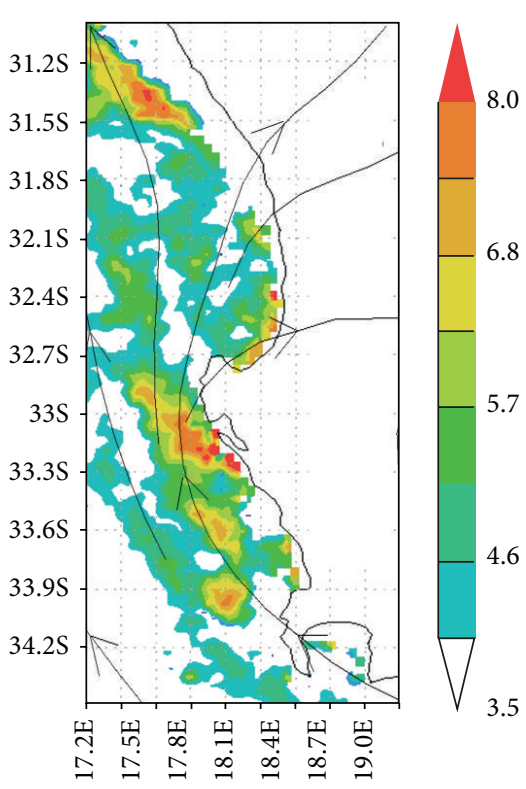

(b)

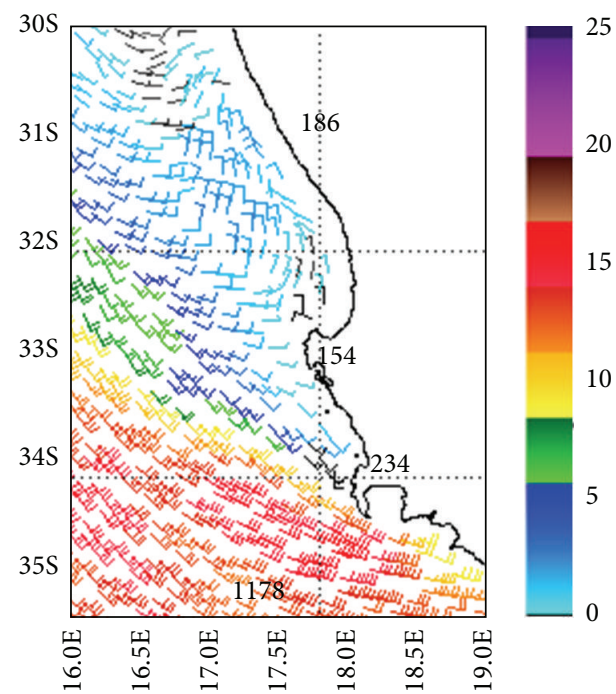

(d)

FIgURE 3: (a) Meteosat $4 \mathrm{~km}$ infrared image and CFS wind vorticity (contours, $10^{-5} \mathrm{~s}^{-1}$ ) for high FLH case of 18 March 2007; (b) MODIS FLH $\left(10^{-2}\right)$ for 14-21 March 2007 and wind streamlines. Scatterometer wind maps (color flags, m/s) for (c) 20 March 2007 and (d) 24 March 2012 with CFS atmospheric mixed layer height $(\mathrm{m})$ labeled at key points.

reports of repeated red tides, low oxygen water, and ecological mortalities in St. Helena Bay in early 2002.

Spatial features of high (daily) FLH events are studied. Wind and surface temperature maps on 18 March 2007 and MODIS FLH in the period from 14 to 21 March are given in Figures 3(a) and 3(b). Southeasterly winds prevailed off the Cape Peninsula and there was a wind shadow in St. Helena Bay. Cyclonic wind vorticity west of the two capes was $\sim-2$ $10^{-5} \mathrm{~s}^{-1}$. Meteosat infrared temperatures exhibited a wide zone of coastal upwelling $<12^{\circ} \mathrm{C}$ and land temperatures above $22^{\circ} \mathrm{C}$. The MODIS 8-day FLH map of 14-21 March 2007 (Figure 3(b)) suggested red tides along the coast of St. Helena
Bay and seaward of the upwelling plumes at $31.3^{\circ} \mathrm{S}$ and $33.1^{\circ} \mathrm{S}$. Scatterometer wind maps for two different high FLH cases are given in Figures 3(c) and 3(d). They exhibit a wind shadow with wind speeds $<7 \mathrm{~m} / \mathrm{s}$ inshore and boundary layer height $\sim 200 \mathrm{~m}$, contrasting with $>15 \mathrm{~m} / \mathrm{s}$ winds in the south and boundary layer height $\sim 1 \mathrm{~km}$. On 24 March 2012, there was a long shear line NW of the Cape Peninsula, initiated by friction of the Hottentots Holland Mountains and reinforced by negative sensible heat fluxes $\left(-20 \mathrm{~W} \mathrm{~m}^{-2}\right)$ over the upwelling zone. In St. Helena Bay, the winds curled cyclonically, and poleward wind flow was observed along the Namaqua Coast. The surface temperature and wind patterns in two further 


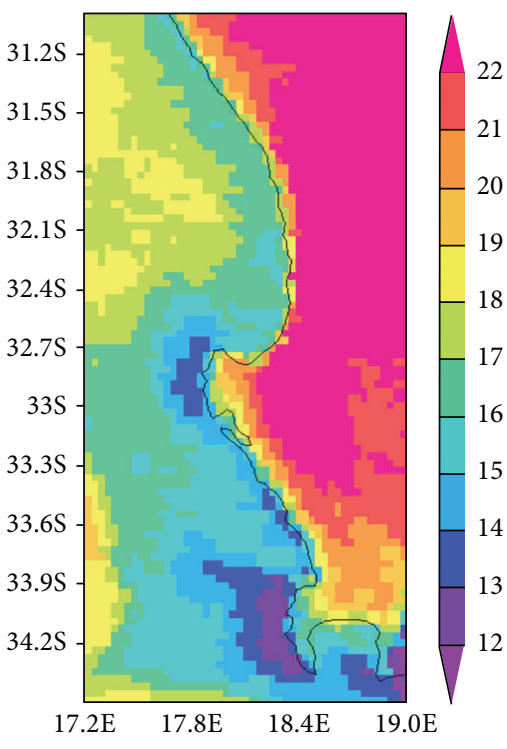

(a)

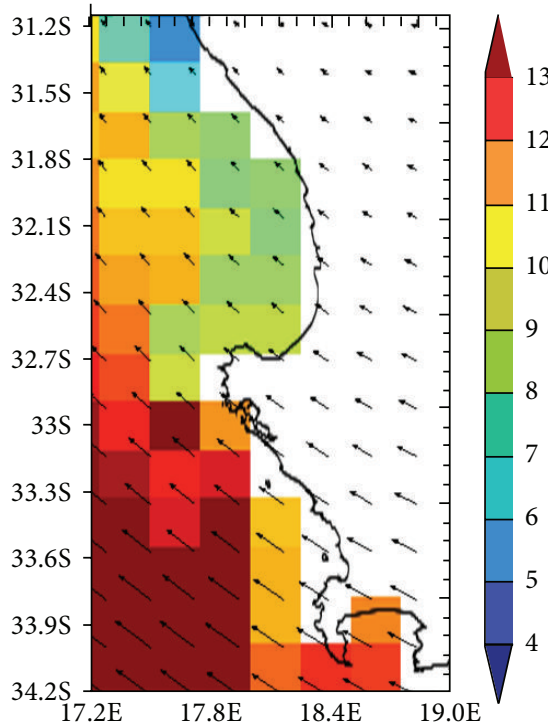

(c)

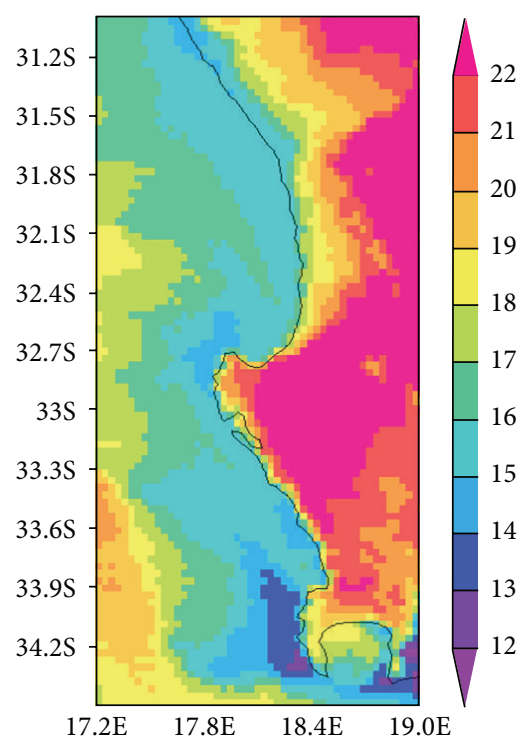

(b)

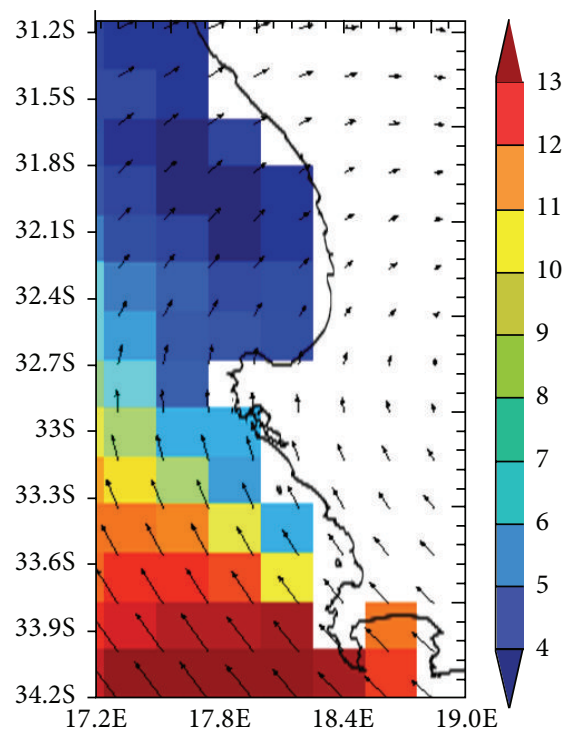

(d)

FIGURE 4: Meteosat 4 km infrared images for two high FLH cases: (a) 7 March 2002 and (b) 24 March 2012, all at 20:00 LST. (c, d) Scatterometer $25 \mathrm{~km}$ gridded wind speed (shaded, $\mathrm{m} / \mathrm{s}$ ) and CFS wind stress vectors for the same cases.

high FLH cases are analyzed in Figures 4(a)-4(d). All share similar features: the upwelling zone was wider and further south than usual. SSTs were $<13^{\circ} \mathrm{C}$ off the cape at $34^{\circ} \mathrm{S}$ and $\sim 16^{\circ} \mathrm{C}$ in St. Helena Bay. Land surface temperatures (at 20:00 LST) were well above $22^{\circ} \mathrm{C}$ and the satellite imagery was cloud-free due to offshore wind flow. Scatterometer winds were $>12 \mathrm{~m} / \mathrm{s}$ in the south, and there was a broad wind shadow $<4 \mathrm{~m} / \mathrm{s}$ to the north where stress vectors turned clockwise.

The 8-day FLH time series (Figure 5(a)) that is the basis for most analyses is filled with high and low spells embedded in a background seasonal rhythm. Multiple regression of surface weather variables yields an algorithm fitting $28 \%$ of variance with negative influences from PAR, zonal wind, and SST and with positive influences from meridional wind and humidity (Table 5). A higher fit could be possible with subsurface ocean variables, but these are not available at multiday time scales. Fitting continuous data provides insights into the seasonal forcing of red tide. However, peak events tend to occur in February-April, wherein seven cases (Table 1, cf. [52]) are used to calculate daily and 8-day composite maps of environmental conditions. Within each high FLH spell, there is a ridging anticyclone-coastal low event that stands out. The composite SLP map sequence (Figure 5(b)) reveals an anticyclone moving eastward along $40^{\circ} \mathrm{S}$, reaching $20^{\circ} \mathrm{E}$ on day -0 and $33^{\circ} \mathrm{E}$ on day +1 , while a coastal low event shifts from $28^{\circ} \mathrm{S}$ to $32^{\circ} \mathrm{S}$. An important feature for red tides is the repetition of this weather sequence and development of a west coast trough to the north of an anticyclone belt. 


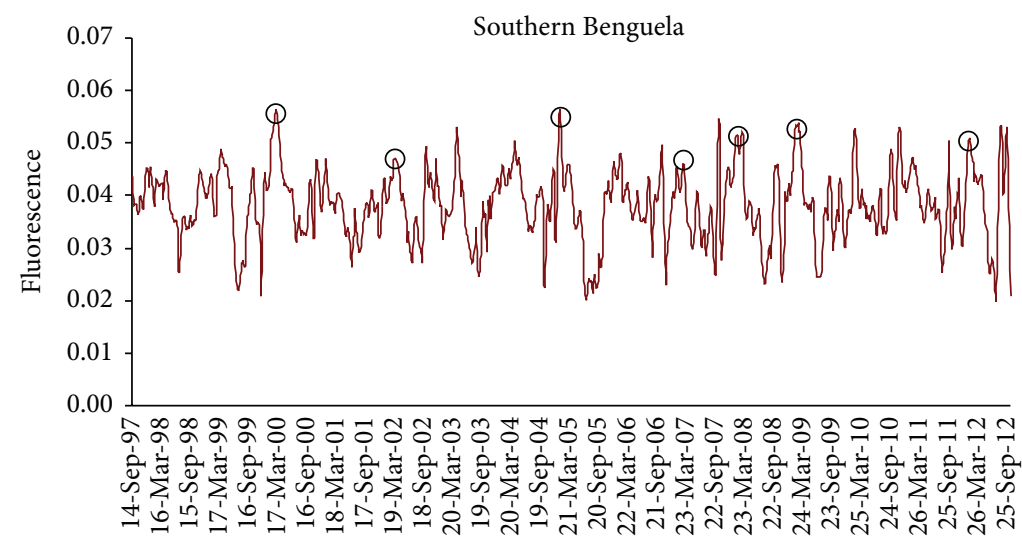

(a)
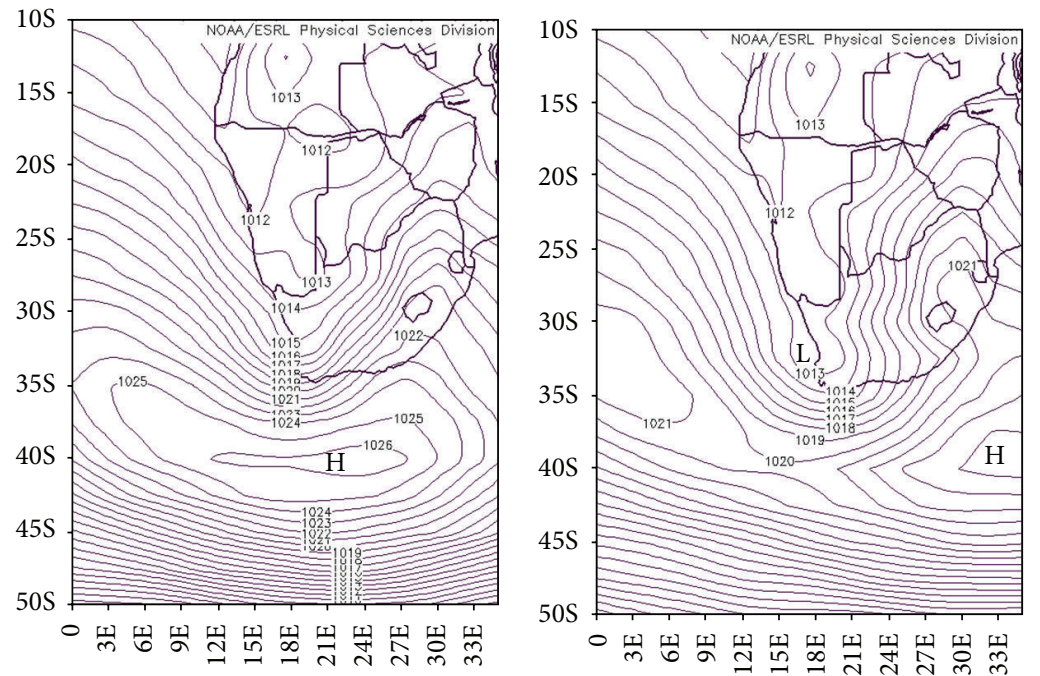

(b)

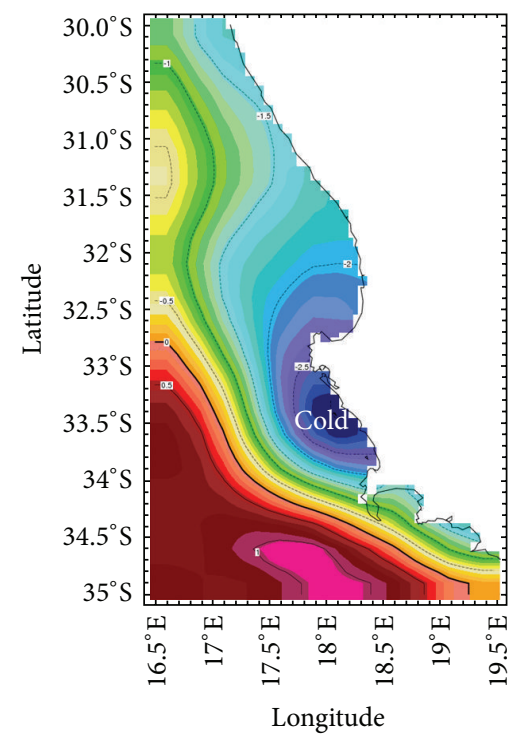

(c)

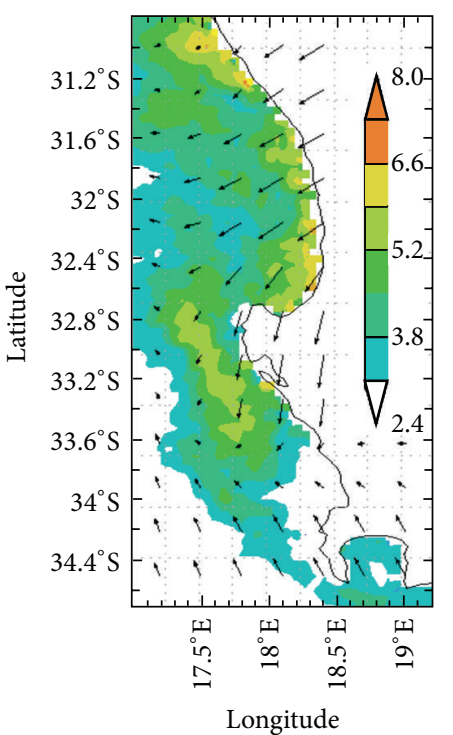

(d)

Figure 5: (a) Time series of 8-day Sea-WiFS/MODIS fluorescence (area as in Figure 2(e)) with circles to identify the 7 high FLH cases confirmed by in situ reports. (b) Composite high day- 0 (left) and day +1 sea level air pressure maps. (c) Composite high day-0 SST anomaly. (d) Example of MODIS FLH $\left(10^{-2}\right)$ and ECMWF wind stress anomalies $\left(\max =0.08 \mathrm{Nm}^{-2}\right)$ in February-March 2005. 


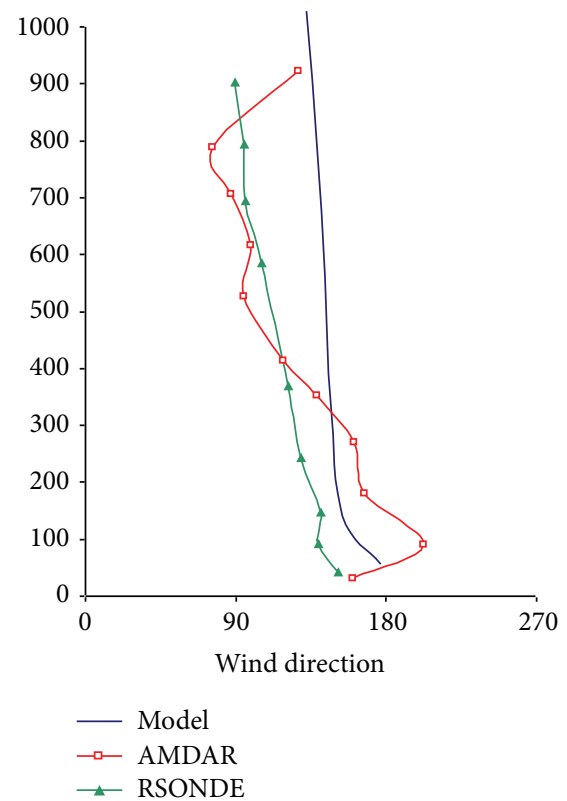

(a)

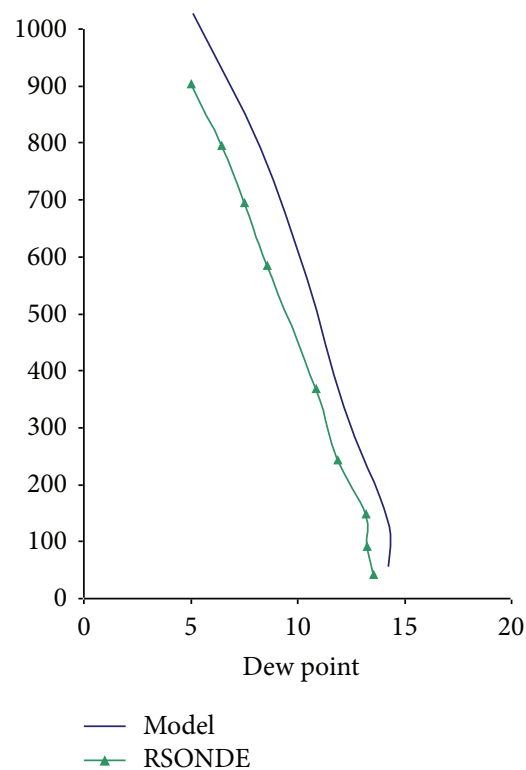

(c)

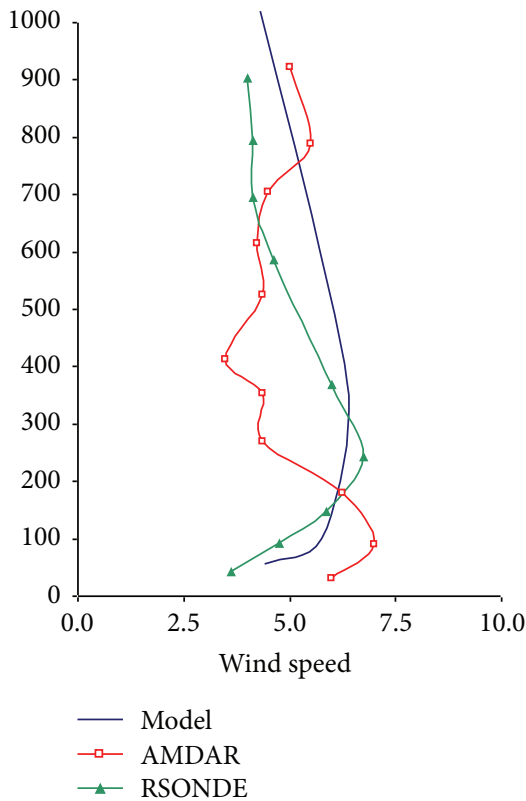

(b)

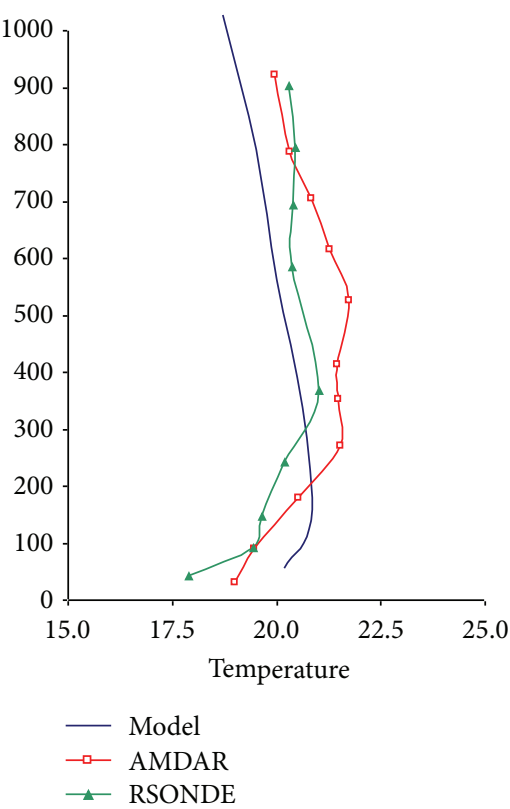

(d)

FIGURE 6: Composite (a) wind direction, (b) wind speed (m/s), (c) dew point, and (d) temperature (C) profiles with height (m) for high daily FLH cases from NCEP model assimilation, AMDAR aircraft, and radiosonde near Cape Town.

The composite SST anomaly map for high FLH cases (Figure 5(c)) has a cold anomaly between the two capes that represents a broadening of the upwelling zone. There is a warm anomaly offshore, so the thermal gradient is strengthened. The MODIS satellite FLH composite in FebruaryMarch 2005 (Figure 5(d)) exhibits high values along the Namaqua and St. Helena Bay coasts and in a meridional axis west of Cape Columbine. Low FLH values are noted in the Cape Peninsula upwelling plume. Wind stress anomalies during February-March 2005 were poleward in the vicinity of Cape Columbine.

3.3. Structure of High Fluorescence Spells. The coastal environment accompanying red tides in the Southern Benguela is studied. Past research has identified that ocean stratification is important, but what about the atmosphere? In Figure 6, composite atmospheric profiles from NCEP model assimilation, 


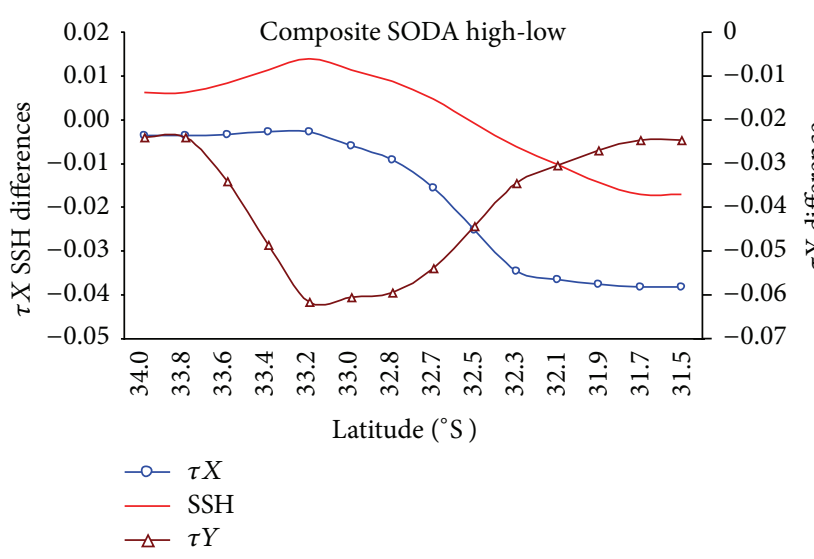

Composite SODA high-low

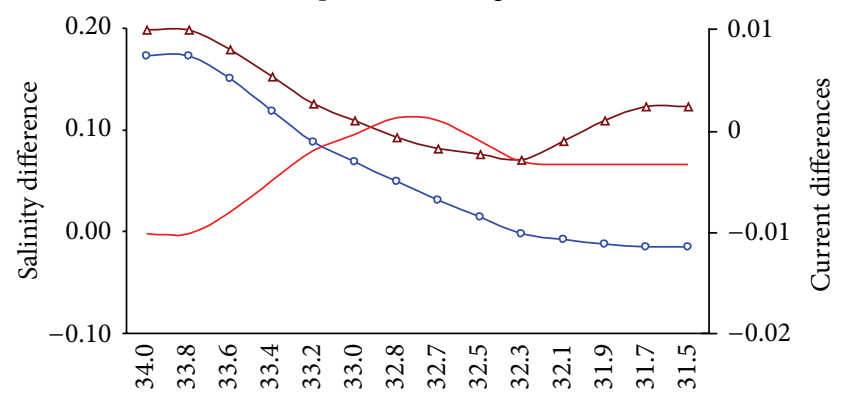

Latitude $\left({ }^{\circ} \mathrm{S}\right)$

- - Salt

$\rightarrow U$

- V

(a)

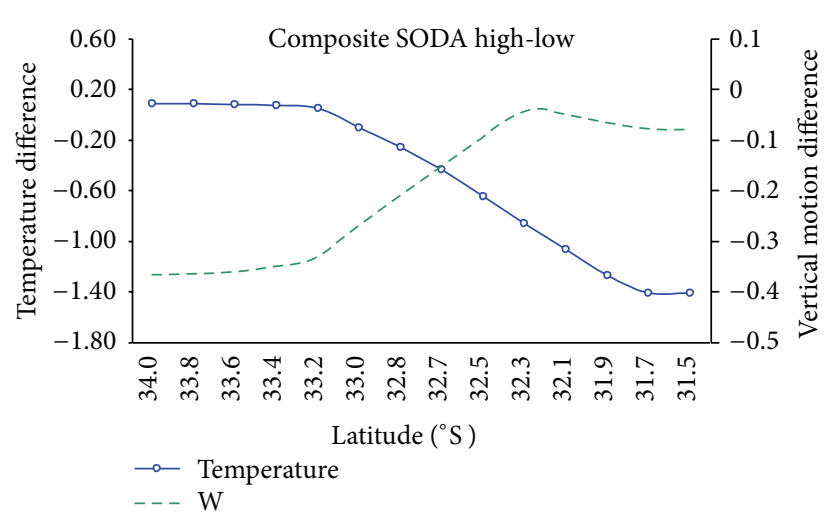

(b)

(c)

Figure 7: Composite 7 high minus 7 low FLH months averaged $17.5-18.5^{\circ} \mathrm{E}$ from SODA for the following: (a) wind stress and sea height, (b) currents and salinity, and (c) temperature and vertical motion differences, to study alongshore gradients.

TABLE 4: Multiple regression statistics: daily FLH index, Nov. 01-Jul. 02 .

\begin{tabular}{lcccc}
\hline Adj. $R$ sq. & 0.52 & & & \\
Std. error & 2.27 & & & \\
Obs. & 273.0 & & & \\
\hline ANOVA & df & SS & MS & $F$ \\
\hline Regression & 6.0 & 1558.2 & 259.7 & 50.2 \\
Residual & 266.0 & 1375.1 & 5.17 & \\
Total & $\mathbf{2 7 2 . 0}$ & $\mathbf{2 9 3 3 . 3}$ & & \\
\hline Std. variables & Coeff. & Std. error & $t$ stat & $P$ value \\
\hline Intercept & 4.512 & 0.172 & 26.2 & 0.000 \\
U wind & -1.061 & 0.107 & -9.9 & 0.000 \\
V wind & -0.443 & 0.086 & -5.1 & 0.000 \\
SST & -0.495 & 0.054 & -9.1 & 0.000 \\
s-n SLP & -0.671 & 0.077 & -8.7 & 0.000 \\
M.L. depth & -0.790 & 0.060 & -13.2 & 0.000 \\
Prec. water & 0.280 & 0.054 & 5.1 & 0.000 \\
\hline
\end{tabular}

AMDAR aircraft, and radiosonde near Cape Town are analyzed for high daily FLH cases. Winds directions tend to be
TABLE 5: Multiple regression statistics: 8-day FLH index, Sep. 97Dec. 12 .

\begin{tabular}{lcccc}
\hline Adj. $R$ sq. & 0.28 & & & \\
Std. error & 0.01 & & & \\
Obs. & 704.0 & & & \\
\hline ANOVA & $\mathrm{df}$ & SS & MS & $F$ \\
\hline Regression & 5.0 & 0.02 & 0.00 & 54.78 \\
Residual & 698.0 & 0.04 & 0.00 & \\
Total & $\mathbf{7 0 3 . 0}$ & $\mathbf{0 . 0 6}$ & & \\
\hline Variables & Coeff. & Std. error & $t$ stat & $P$ value \\
\hline Intercept & 0.05 & 0.00 & 12.93 & 0.000 \\
PAR & -0.0002 & 0.00 & -5.27 & 0.000 \\
U ncep & -0.0009 & 0.00 & -3.94 & 0.000 \\
V ncep & 0.0013 & 0.00 & 5.04 & 0.000 \\
Humidity & 0.0036 & 0.00 & 10.19 & 0.000 \\
SST & -0.0026 & 0.00 & -6.77 & 0.000 \\
\hline
\end{tabular}

southerly to varying degrees and shift to easterly with height, as expected from the Ekman spiral effect of surface friction. Model and radiosonde wind direction profiles are smoother 

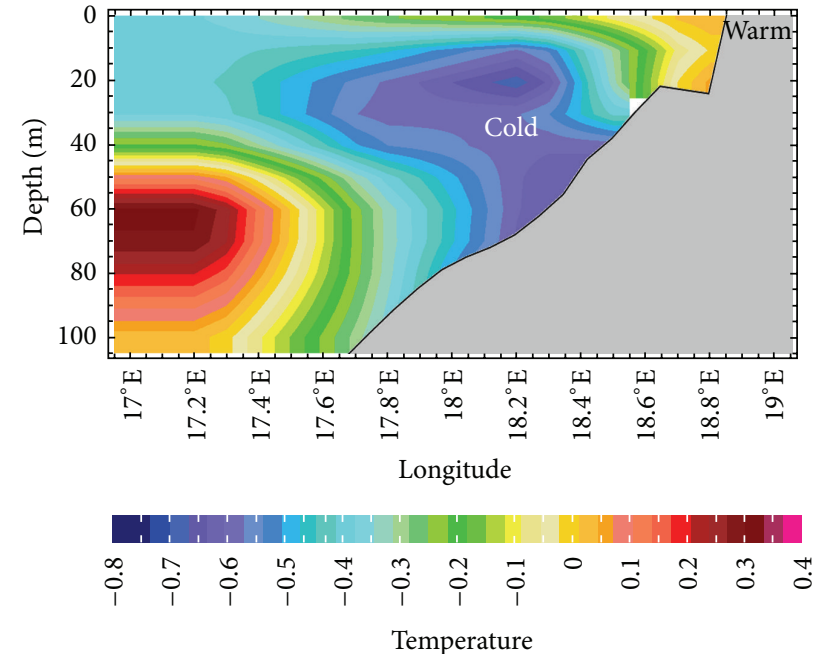

(a)

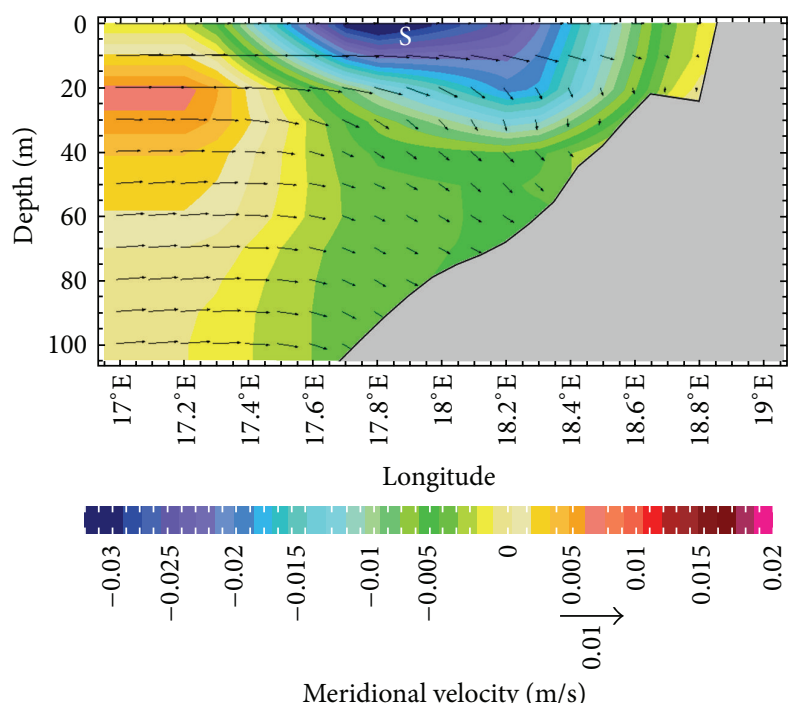

(c)

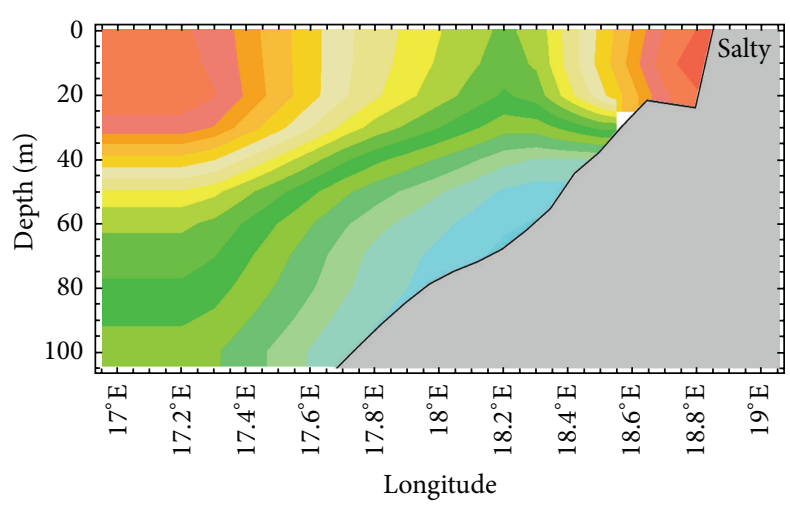

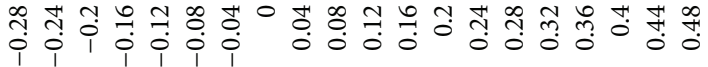

Salinity $(\mathrm{g} / \mathrm{kg})$

(b)

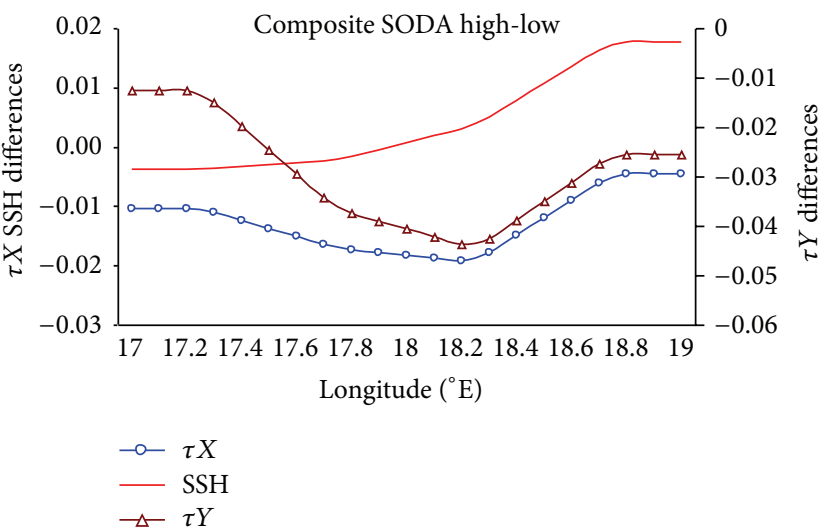

(d)

Figure 8: Composite 7 high minus 7 low FLH months averaged 34-31.5 $\mathrm{S}$ from SODA for the following: (a) temperature, (b) salinity, (c) currents: meridional differences shaded, zonal overturning vectors $\max =0.02 \mathrm{~m} / \mathrm{s}$, and (d) wind stress and sea height differences, to study cross-shelf gradients.

than aircraft. Wind speeds exhibit a near-surface coastal jet of varying thickness, with strongest winds from 100 to $200 \mathrm{~m}$ in aircraft and radiosonde profiles, and somewhat deeper in the model representation. Dew point temperatures are 10$15^{\circ} \mathrm{C}$ and decrease with height consistent with dry easterly downslope flow, locally known as "berg winds." Temperature inversions are found in all profiles, indicative of stable atmospheric conditions that inhibit turbulent momentum transfer at the top of the mixed layer. The increase is $\sim 4^{\circ} \mathrm{C}$ from $10 \mathrm{~m}$ to $500 \mathrm{~m}$ in aircraft and radiosonde profiles and weaker in the model analysis. With surface air temperatures near $18^{\circ} \mathrm{C}$ and coastal SST below $15^{\circ} \mathrm{C}$, an inversion exists over the upwelling zone which helps to maintain the wind shadow.
Composite ocean structure for seven high minus low FLH months (cf. Table 1) is illustrated in Figures 7(a)-7(c) along coast axis. A key feature is the negative ECMWF meridional wind stress difference indicating a wind shadow over Cape Columbine $\left(33.2-32.7^{\circ} \mathrm{S}\right)$. Zonal wind stress is neutral in the south but westward (-) over the Namaqua coast $\left(32.3-31.5^{\circ} \mathrm{S}\right)$, indicating berg winds. Sea surface height shows a positive difference in the wind shadow and a negative slope to the north. Composite SODA currents are onshore- and poleward-directed to the south, suggesting a "pulling" action on shelf waters. Salinity differences are positive in the south with a slope toward neutral conditions elsewhere. SODA subsurface temperature differences are neutral in the south and exhibit a 


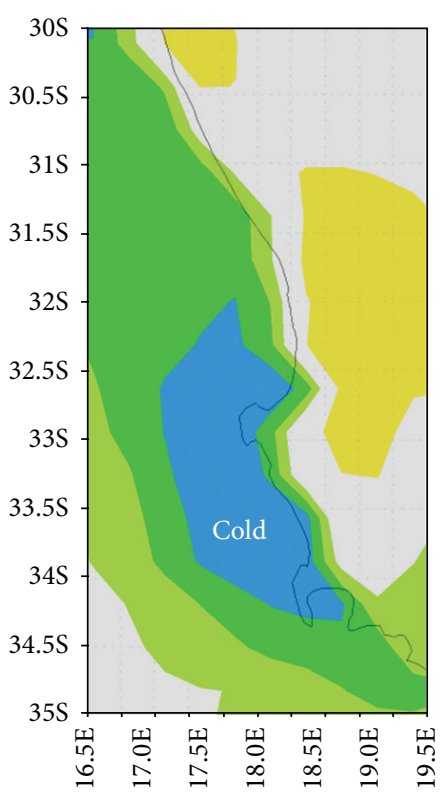

(a)

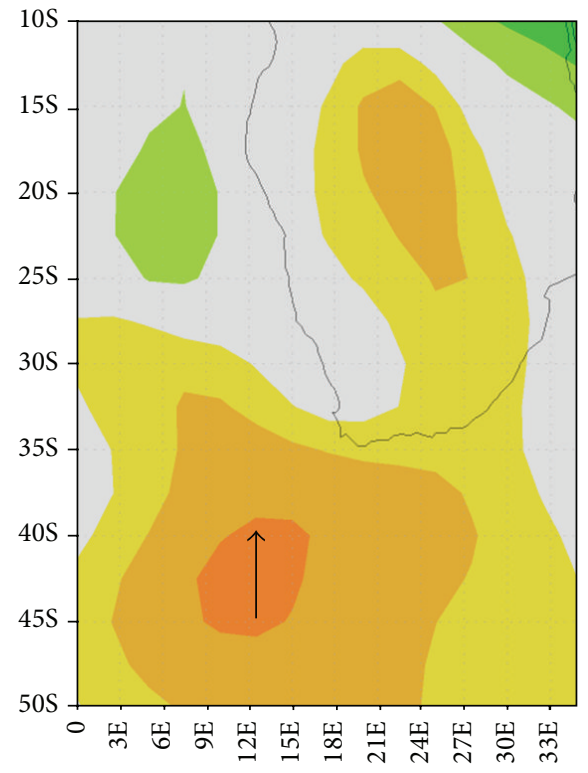

(d)

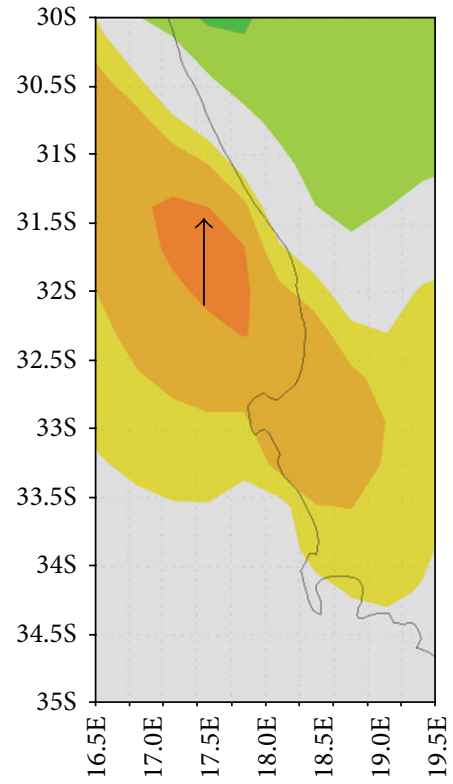

(b)

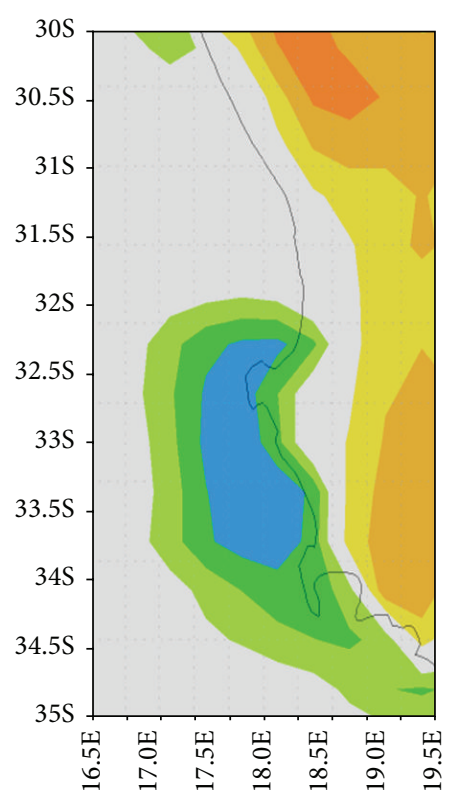

(c)

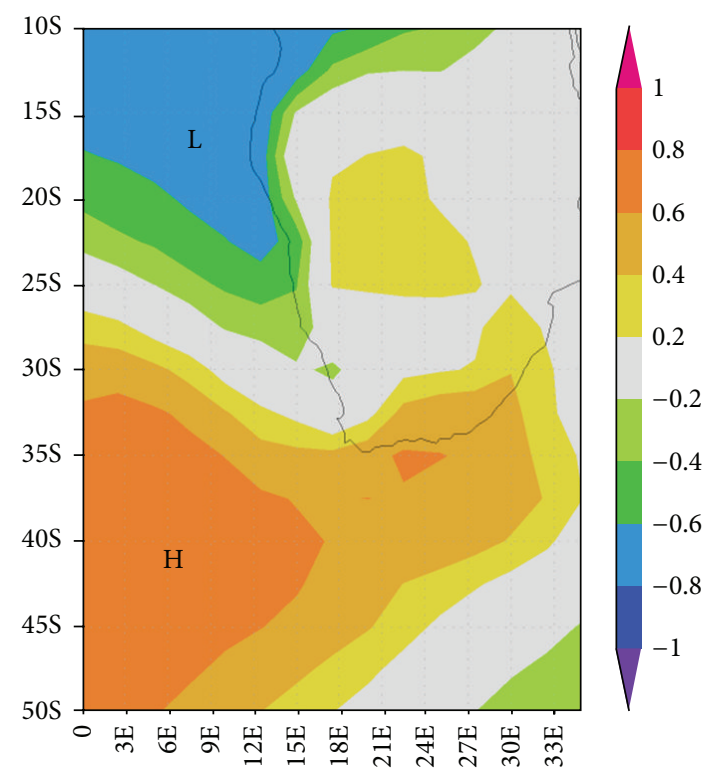

(e)

FIgURE 9: Correlation maps using February-April FLH index with CFS reanalysis: (a) surface temperature $T_{s}$, (b) meridional wind stress tau $Y$, (c) latent heat flux $Q_{e}$, (d) $200 \mathrm{mb}$ meridional wind V200, and (e) sea level air pressure SLP. Values of $|r|>0.40$ significant at $90 \%$ confidence in the period 1998-2010.

gradient toward cold conditions north of Cape Columbine: a broadening of the upwelling zone there. Vertical motion differences are the inverse: negative (downwelling) in the south and neutral elsewhere.

Composite ocean structure for high minus low FLH months is analyzed as cross-shelf sections in Figures 8(a)$8(d)$. These help to identify the "climate envelope," within which the red tides events are formed. The temperaturesalinity sections identify subsurface cold $\left(-0.7^{\circ} \mathrm{C}\right)$ fresh differences on the shelf edge $\left(18.0^{\circ} \mathrm{E}\right)$ denoting a relic upwelling plume, while warm differences are located offshore. Most significantly, the SODA reanalysis detects the warm salty surface layer at the coast $\left(18.6^{\circ} \mathrm{E}\right)$. The current differences reveal several features consistent with in situ surveys during red tide [53]. A zonal downwelling circulation is found, with poleward flow differences $(-0.03 \mathrm{~m} / \mathrm{s})$ in the upper layer from 17.8 to $18.4^{\circ} \mathrm{E}$. The cross-shelf structure of wind stress differences is most negative at $18.2^{\circ} \mathrm{E}$. The $\mathrm{V}$-shape indicates shear lines that separate active upwelling and quiescent zones. The sea surface height is elevated on the coast due to onshore transport and 


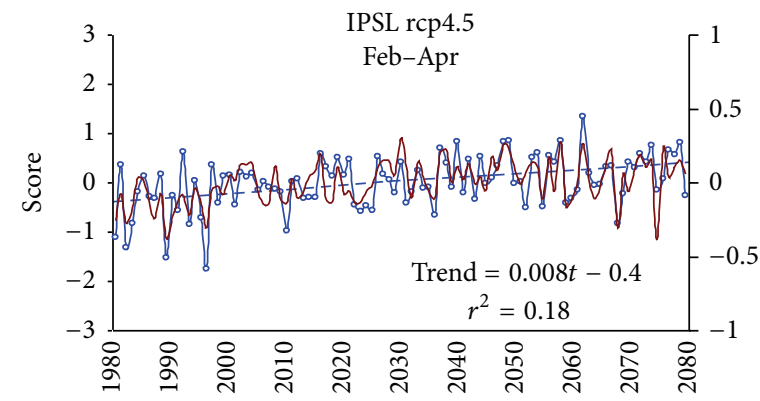

(SLP1)

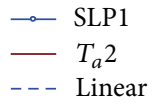

(a)

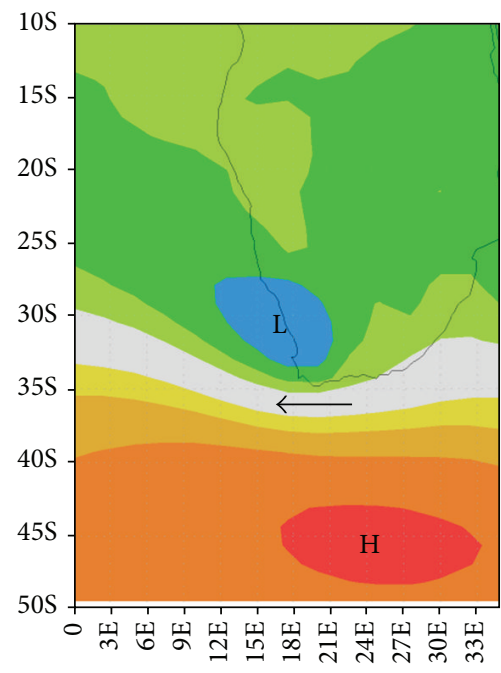

(b)

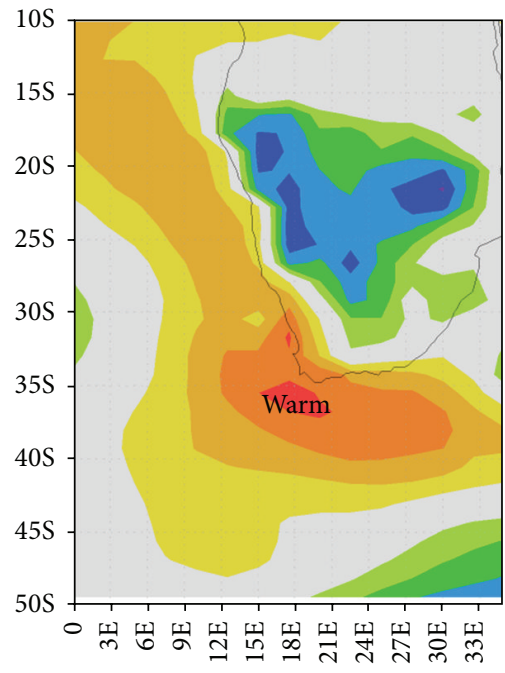

(c)

FIGURE 10: (a) February-April principal component scores for SLP1 (38\%) and $T_{a} 2$ (11\%) based on IPSL simulation and (b, c) their loading patterns. Linear trend for SLP1 refers to increasing ridging high, coastal trough pattern, contributing to warm easterly winds over the Southern Benguela.

supports surface poleward currents. It is suggested that the ability of $50 \mathrm{~km}$ resolution ocean reanalysis products to represent many known features underlying red tides in the Southern Benguela means that operational forecasts of conditions suitable for red tide are within reach.

\subsection{Environmental Influences on Seasonal Fluorescence. FLH} index-to-field correlations are analyzed for the FebruaryApril season in Figures 9(a)-9(e). This analysis promotes an understanding of the interannual forcing of red tides. The CFS correlation maps exhibit a pattern of increased upwelling and equatorward wind flow in respect of high FLH seasons. Surface temperature correlations are negative in the upwelling zone $(r<-0.4)$ and positive inland. Wind stress correlations are positive and upwelling favorable, but negative correlations with latent heat flux suggest light winds between the two capes. Further inland there are positive correlations referring to increased moisture flux. Taking a wider perspective (Figure 9(d)), the FLH index-to-field correlations are positive (equatorward) for meridional upper winds and refer to an anticyclonic ridge in the midlatitude jet stream. The sea level air pressure map is most important (Figure 9(e)). It exhibits south-high/north-low values: a ridged anticyclonewest coast trough weather pattern. Thus, the climate "envelope" contains event-like features that could enable forecasts at long lead times.

Coupled model simulations that form part of the IPCC CMIP5 assessment are available for analysis here. Use is made of the IPSL5 model outputs for SLP and $T_{a}$ with an rcp $4.5 \mathrm{~W} / \mathrm{m}^{2}$ scenario, considering the principal component time scores and loading patterns (Figures 10(a)-10(c)). The leading SLP mode is the ridged anticyclone-west coast trough pattern explaining 38\% of variance in February to April season over the period 1980-2080. The IPSL5 model, which 
represents the Benguela upwelling zone better than most, predicts a poleward shift of subtropical anticyclones as $\mathrm{CO}_{2}$ rises. With more easterly winds, the west coast trough deepens. The SLP1 loading pattern of IPSL5 (Figure 10(b)) resembles the FLH-SLP map (Figure 9(e)). The upward trend of its time score (18\% of variance, Figure 10(a)) suggests that the frequency of red tide events could grow in the Southern Benguela, as the wind shadow widens. Concurrently, the easterly winds raise air temperatures over the upwelling zone (Figure 10(c)), giving rise to stronger inversions that promote cyclonic wind shear. These changes are underway, drawing the fisheries southward along the coast [54].

\section{Summarizing Discussion}

This exploration of environmental influences on red tide initially considered a wide variety of spatial and temporal scales and satellite proxies. Following statistical tests, the 8day fluorescence line height averaged $34-31.5^{\circ} \mathrm{S}, 17.5-18.5^{\circ} \mathrm{E}$ appeared to be the best indicator and yields the most in situ confirmations. Local ship and aerial surveys have found that red tides form in $\sim 5 \times 20 \mathrm{~km}$ patches and accumulate over a few days [14-16], mainly in February to April season. Efforts to detect and predict red tides have focused on local observations and nested models over multiday events. Here, $30-50 \mathrm{~km}$ monthly reanalysis fields have identified the key environmental forcing. The large scale weather is comprised of ridging anticyclone and west coast trough which generates sustained easterly winds over the Cape Peninsula and cold upwelling plumes that extend $>100 \mathrm{~km}$ seaward (Figures 3 (b) and $4(\mathrm{a})-4(\mathrm{c}))$. As the weather evolves into a quiescent phase, there is poleward Ekman transport and inshore warming. The composite SLP anomaly south of Cape Town reaches $+9 \mathrm{mb}$ during high FLH cases. The climate "envelope" contains repeated red tide weather events (compare Figures 5(b) and 9(e)) involving a retreat of the circumpolar westerlies and an atmospheric ridge south of Cape Town (Figure 9(d)). These features can be forecast by global models at seasonal lead times.

The windward cape-leeward bay geography creates upwelling shadows where increased residence time builds phytoplankton biomass and harmful dinoflagellate blooms [5559]. Alongshore winds and currents accelerated by the cape sweep clockwise into the leeward bay (Figure 3(f)). The upwelling shadow promotes onshore poleward currents (Figure 8(c)) and thermal stability (Figures 8(a) and 8(b)) which transports and concentrates red tides near the coast. As they dissipate and decay, anoxic water stresses the marine life. The economic consequences of red tides could be mitigated through improved forecasts of its environmental forcing as outlined here. Further progress can be made by employing higher resolution daily products such as the $8 \mathrm{~km}$ HYCOM-NCODA model assimilation from http://apdrc.soest.hawaii.edu/las8.

\section{Conflict of Interests}

The author declares that there is no conflict of interests regarding the publication of this paper.

\section{Acknowledgments}

The data suppliers are acknowledged: MCM (red-tide cases), NCEP-NOMAD (CFS daily), NASA-Giovanni (SeaWiFS/MODIS color, Meteosat IR), IRI Climate Library (SODA, ECMWF, and MODIS Ts), Climate Explorer KNMI (CFS monthly, correlation, and PC analysis), APDRC-Hawaii (JOFURO winds), NOAA-AMDAR (aircraft profiles), and NESDIS-MANATI (scatterometer winds).

\section{References}

[1] G. Nelson and L. Hutchings, "The Benguela upwelling area," Progress in Oceanography, vol. 12, no. 3, pp. 333-356, 1983.

[2] J. Rogers and J. M. Bremner, "The Benguela ecosystem part I. Evolution of the Benguela, physical features and processes," Oceanography and Marine Biology: An Annual Review, vol. 23, pp. 105-182, 1995.

[3] S. L. Garzoli and A. L. Gordon, "Origins and variability of the Benguela current," Journal of Geophysical Research, vol. 101, no. 1, pp. 897-906, 1996.

[4] L. V. Shannon and G. Nelson, "The Benguela: large scale features and processes and system variability," in The South Atlantic: Present and Past Circulation, G. Wefer, W. H. Berger, G. Siedler, and D. J. Webb, Eds., pp. 163-210, Springer, Berlin, Germany, 1996.

[5] M. R. Jury, "The spatial distribution of wind driven upwelling off the West coast of Africa," Continental Shelf Research, vol. 8, no. 11, pp. 1257-1271, 1988.

[6] A. Bakun and C. S. Nelson, "The seasonal cycle of wind-stress curl in subtropical eastern boundary current regions," Journal of Physical Oceanography, vol. 21, no. 12, pp. 1815-1834, 1991.

[7] W. Fennel, “Theory of the Benguela upwelling system," Journal of Physical Oceanography, vol. 29, no. 2, pp. 177-190, 1999.

[8] M. R. Jury, "Mesoscale variations in summer wind over the Cape Columbine-St Helena Bay region," South African Journal of Marine Science, vol. 3, no. 1, pp. 77-88, 1985.

[9] G. C. Pitcher, P. Monteiro, and A. Kemp, "The potential use of a hydrodynamic model in the prediction of harmful algal blooms in the Southern Benguela," in Harmful Algae 2002, K. A. Steidinger, J. H. Landsberg, C. R. Tomas, and G. A. Vargo, Eds., pp. 11-13, Florida Fish and Wildlife Conservation Commission Florida Institute of Oceanography, Intergovernmental Oceanographic Commission of UNESCO, 2004.

[10] C. J. Holden, "Currents in St Helena Bay inferred from radiotracked drifters," in South African Ocean Colour and Upwelling Experiment, L. V. Shannon, Ed., pp. 97-109, Sea Fisheries Research, 1985.

[11] R. Lamberth and G. Nelson, "Field and analytical drogue studies applicable to the St Helena Bay area off South Africa's West coast," in The Benguela and Comparable Ecosystems, A. L. Payne, J. A. Gulland, and K. H. Brink, Eds., vol. 5, pp. 163-169, African Journal of Marine Science, 1987.

[12] P. Penven, C. Roy, A. C. de Verdière, and J. Largier, "Simulation of a coastal jet retention process using a barotropic model," Oceanologica Acta, vol. 23, no. 5, pp. 615-634, 2000.

[13] G. C. Pitcher and D. Calder, "Harmful algal blooms of the Southern Benguela current: a review and appraisal of monitoring from 1989-1997," South African Journal of Marine Science, no. 22, pp. 255-271, 2000. 
[14] P. L. Donaghay and T. R. Osborn, "Toward a theory of biological-physical control of harmful algal bloom dynamics and impacts," Limnology and Oceanography, vol. 42, no. 5, pp. 12831296, 1998.

[15] G. C. Pitcher, A. J. Richardson, and J. L. Korrubel, “The use of sea temperature in characterizing the mesoscale heterogeneity of phytoplankton in an embayment of the Southern Benguela upwelling system," Journal of Plankton Research, vol. 18, no. 5, pp. 643-657, 1996.

[16] G. C. Pitcher, A. J. Boyd, D. A. Horstman, and B. A. MitchellInnes, "Subsurface dinoflagellate populations, frontal blooms and the formation of red tide in the Southern Benguela upwelling system," Marine Ecology Progress Series, vol. 172, pp. 253-264, 1998.

[17] C. J. Reason and M. R. Jury, "On the generation and propagation of the Southern African coastal low," Quarterly Journal of the Royal Meteorological Society, vol. 116, no. 495, pp. 1133-1151, 1990.

[18] M. R. Jury and G. B. Brundrit, "Temporal organization of upwelling in the Southern Benguela ecosystem by resonant coastal trapped waves in the ocean and atmosphere," South African Journal of Marine Science, vol. 12, pp. 219-224, 1992.

[19] T. A. Probyn, G. C. Pitcher, P. Monteiro, A. J. Boyd, and G. Nelson, "Physical processes contributing to harmful algal blooms in Saldanha Bay, South Africa," South African Journal of Marine Science, no. 22, pp. 285-297, 2000.

[20] U. Send, R. C. Beardsley, and C. D. Winant, "Relaxation from upwelling in the Coastal Ocean Dynamics Experiment," Journal of Geophysical Research, vol. 92, no. C2, pp. 1683-1698, 1987.

[21] G. C. Pitcher, J. Agenbag, D. Calder, D. Horstman, M. R. Jury, and J. Taunton-Clark, "Red tides in relation to the meteorology of the Southern Benguela upwelling systemp," in Harmful Marine Algal Blooms, P. Lassus, G. Arzul, E. Erard, P. Gentien, and C. Marcaillou, Eds., pp. 657-662, Intercept, 1995.

[22] J. J. Cullen and J. G. MacIntyre, "Behaviour, physiology and the niche of depth-regulating phytoplankton," in Physiological Ecology of Harmful Algal Blooms, D. M. Anderson, A. D. Cembella, and G. M. Hallegraeff, Eds., vol. G 41 of NATO ASI, pp. 559-579, Springer, Berlin, Germany, 1998.

[23] M. Estrada and E. Berdalet, "Effects of turbulence on phytoplankton," in Physiological Ecology of Harmful Algal Blooms, D. M. Anderson, A. D. Cembella, and G. M. Hallegraeff, Eds., vol. G 41 of NATO ASI, pp. 601-618, Springer, 1998.

[24] T. J. Smayda and C. S. Reynolds, "Community assembly in marine phytoplankton: application of recent models to harmful dinoflagellate blooms," Journal of Plankton Research, vol. 23, no. 5, pp. 447-461, 2001.

[25] G. C. Pitcher and A. J. Boyd, "Across-shelf and alongshore dinoflagellate distributions and the mechanisms of red tide formation within the Southern Benguela upwelling system," in Harmful and Toxic Algal Blooms, T. Yasumoto, Y. Oshima, and Y. Fukuyo, Eds., pp. 243-246, Intergovernmental Oceanographic Commission of UNESCO, 1996.
[26] A. C. Cockcroft, D. S. Schoeman, G. C. Pitcher, G. W. Bailey, and D. C. VanZyl, "A mass stranding, or "walkout" of West coast rock lobster Jasus lalandii in Elands Bay, South Africa: causes, results and implications," in Biodiversity Crises and Crustacea, J. C. von Kaupel Klein and F. R. Schram, Eds., Crustacean Issues, pp. 362-688, 2000.

[27] G. C. Pitcher and T. A. Probyn, "Anoxia in Southern Benguela during the autumn of 2009 and its linkage to a bloom of the dinoflagellate Ceratium balechii," Harmful Algae, vol. 11, pp. 2332, 2011.

[28] S. J. Weeks, G. C. Pitcher, and S. Bernard, "Satellite monitoring of the evolution of a coccolithophorid bloom in the Southern Benguela upwelling system," Oceanography, vol. 17, no. 1, pp. 8389, 2004.

[29] L. Shen, X. Huiping, and X. Guo, "Satellite remote sensing of harmful algal blooms and a potential synthesized framework," Sensors, vol. 12, no. 6, pp. 7778-7803, 2012.

[30] R. M. Letelier and M. R. Abbott, "An analysis of chlorophyll fluorescence algorithms for the moderate resolution imaging spectrometer (MODIS)," Remote Sensing of Environment, vol. 58, no. 2, pp. 215-223, 1996.

[31] C. M. Hu, F. E. Muller-Karger, C. J. Taylor et al., "Red tide detection and tracing using MODIS fluorescence data: a regional example in SW Florida coastal waters," Remote Sensing of Environment, vol. 97, no. 3, pp. 311-321, 2005.

[32] M. C. Tomlinson, T. T. Wynne, and R. P. Stumpf, "An evaluation of remote sensing techniques for enhanced detection of the toxic dinoflagellate, Karenia brevis," Remote Sensing of Environment, vol. 113, no. 3, pp. 598-609, 2009.

[33] D. Z. Zhao, X. G. Xing, Y. G. Liu, J. H. Yang, and L. Wang, "The relation of chlorophyll-a concentration with the reflectance peak near $700 \mathrm{~nm}$ in algae-dominated waters and sensitivity of fluorescence algorithms for detecting algal bloom," International Journal of Remote Sensing, vol. 31, no. 1, pp. 39-48, 2010.

[34] T. Kuster, L. Metsamaa, E. Vahtmae, and N. Strömbeck, "On suitability of MODIS $250 \mathrm{~m}$ resolution band data for quantitative mapping cyanobacterial blooms," Journal of Experimental Marine Biology and Ecology, vol. 55, pp. 318-328, 2006.

[35] Y. H. Ahn and P. Shanmugam, "Detecting the red tide algal blooms from satellite ocean color observations in optically complex Northeast-Asia coastal waters," Remote Sensing of Environment, vol. 103, no. 4, pp. 419-437, 2006.

[36] P. S. Schopf and A. Loughe, "A reduced gravity isopycnal ocean model: Hindcasts of El Nino," Monthly Weather Review, vol. 123, no. 9, pp. 2839-2863, 1995.

[37] W. W. Gregg, "Assimilation of SeaWiFS ocean chlorophyll data into a three-dimensional global ocean model," Journal of Marine Systems, vol. 69, no. 3-4, pp. 205-225, 2008.

[38] P. Cury and C. Roy, "Optimal environmental window and pelagic fish recruitment success in upwelling areas," Canadian Journal of Fisheries and Aquatic Sciences, vol. 46, no. 4, pp. 670680, 1989.

[39] L. Hutchings, M. R. Roberts, and H. M. Verheye, "Marine environmental monitoring programmes in South Africa: a review," South African Journal of Science, vol. 105, no. 3-4, pp. 94-102, 2009.

[40] S. E. Nicholson, "A low-level jet along the Benguela coast, an integral part of the Benguela current ecosystem," Climatic Change, vol. 99, no. 3, pp. 613-624, 2010. 
[41] M. R. Jury, "Representation of coastal upwelling in the Southern Benguela by satellite era reanalysis," International Journal of Marine Science, vol. 3, no. 34, pp. 267-277, 2013.

[42] H. Demarcq, "Trends in primary production, sea surface temperature and wind in upwelling systems (1998-2007)," Progress in Oceanography, vol. 83, no. 1-4, pp. 376-385, 2009.

[43] P. Fréon, M. Barange, and J. Arístegui, "Eastern boundary upwelling ecosystems: integrative and comparative approaches," Progress in Oceanography, vol. 83, no. 1-4, pp. 1-14, 2009.

[44] S. Saha, S. Moorthi, and P. Hua-Lu, "The NCEP climate forecast system reanalysis," Bulletin of the American Meteorological Society, vol. 91, pp. 1015-1057, 2010.

[45] J. A. Carton and B. S. Giese, "A reanalysis of ocean climate using simple ocean data assimilation (SODA)," Monthly Weather Review, vol. 136, no. 8, pp. 2999-3017, 2008.

[46] S. M. Griffies, M. J. Harrison, R. C. Pacanowski, and A. Rosati, "Technical guide to MOM4," Technical Report 5, GFDL Ocean Group, Princeton, NJ, USA, 2004.

[47] R. W. Reynolds, T. M. Smith, C. Liu, D. B. Chelton, K. S. Casey, and M. G. Schlax, "Daily high-resolution-blended analyses for sea surface temperature," Journal of Climate, vol. 20, no. 22, pp. 5473-5496, 2007.

[48] M. Kubota, N. Iwasaka, S. Kizu, M. Konda, and K. Kutsuwada, "Japanese ocean flux data sets with use of remote sensing observations (J-OFURO)," Journal of Oceanography, vol. 58, no. 1, pp. 213-225, 2002.

[49] K. E. Taylor, R. J. Stouffer, and G. A. Meehl, "An overview of CMIP5 and the experiment design," Bulletin of the American Meteorological Society, vol. 93, no. 4, pp. 485-498, 2012.

[50] M. R. Jury, "Climate trends in Southern Africa," South African Journal of Science, vol. 109, no. 1-2, article 980, 11 pages, 2013.

[51] J. L. Dufresne, M. A. Foujols, S. Denvil et al., "Climate change projections using the IPSL- $\mathrm{CM}_{5}$ earth system model: from $\mathrm{CMIP}_{3}$ to $\mathrm{CMIP}_{5}$," Climate Dynamics, vol. 40, no. 9-10, pp. 2123-2165, 2013.

[52] C. Roy, S. Weeks, M. Rouault, G. Nelson, R. Barlow, and C. van der Lingen, "Extreme oceanographic events recorded in the Southern Benguela during the 1999-2000 summer season," South African Journal of Science, vol. 97, no. 11-12, pp. 465-471, 2001.

[53] G. C. Pitcher and G. Nelson, "Characteristics of the surface boundary layer important to the development of red tide on the Southern Namaqua shelf of the Benguela upwelling system," Limnology and Oceanography, vol. 51, no. 6, pp. 2660-2674, 2006.

[54] C. Roy, C. van der Lingen, J. C. Coetzee, and J. Lutjeharms, "Abrupt environmental shift associated with changes in the distribution of Cape anchovy Engraulis encrasicolus spawners in the Southern Benguela," African Journal of Marine Science, vol. 29, no. 3, pp. 309-319, 2007.

[55] W. M. Graham and J. L. Largier, "Upwelling shadows as nearshore retention sites: the example of Northern Monterey Bay," Continental Shelf Research, vol. 17, no. 5, pp. 509-532, 1997.

[56] L. B. Joyce, G. C. Pitcher, A. D. Randt, and P. M. S. Monteiro, "Dinoflagellate cysts from surface sediments of Saldanha Bay, South Africa: an indication of the potential risk of harmful algal blooms," Harmful Algae, vol. 4, no. 2, pp. 309-318, 2005.

[57] M. Roughan, A. J. Mace, J. L. Largier, S. G. Morgan, J. L. Fisher, and M. L. Carter, "Subsurface recirculation and larval retention in the lee of a small headland: a variation on the upwelling shadow theme," Journal of Geophysical Research, vol. 110, no. 10, Article ID C10027, pp. 1-18, 2005.
[58] G. C. Pitcher and S. J. Weeks, "The variability and potential for prediction of harmful algal blooms in the Southern Benguela ecosystem," in The Benguela: Predicting a Large Marine Ecosystem, V. Shannon, G. Hempel, P. Malanotte-Rizzoli, C. Moloney, and J. Woods, Eds., pp. 125-146, Elsevier, 2006.

[59] G. C. Pitcher, F. G. Figueiras, B. M. Hickey, and M. T. Moita, "The physical oceanography of upwelling systems and the development of harmful algal blooms," Progress in Oceanography, vol. 85, no. 1-2, pp. 5-32, 2010. 

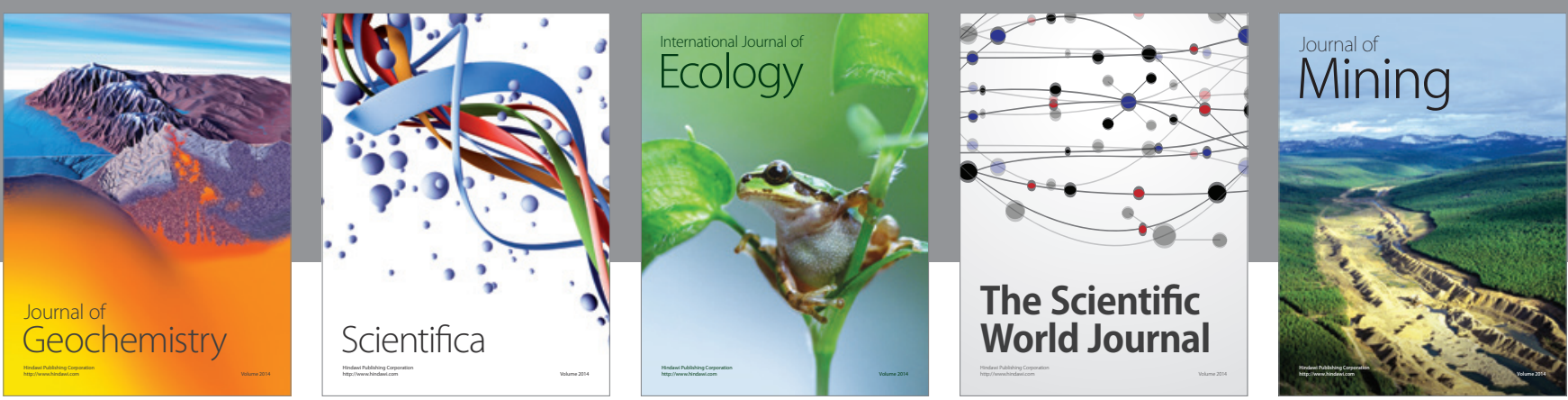

The Scientific World Journal
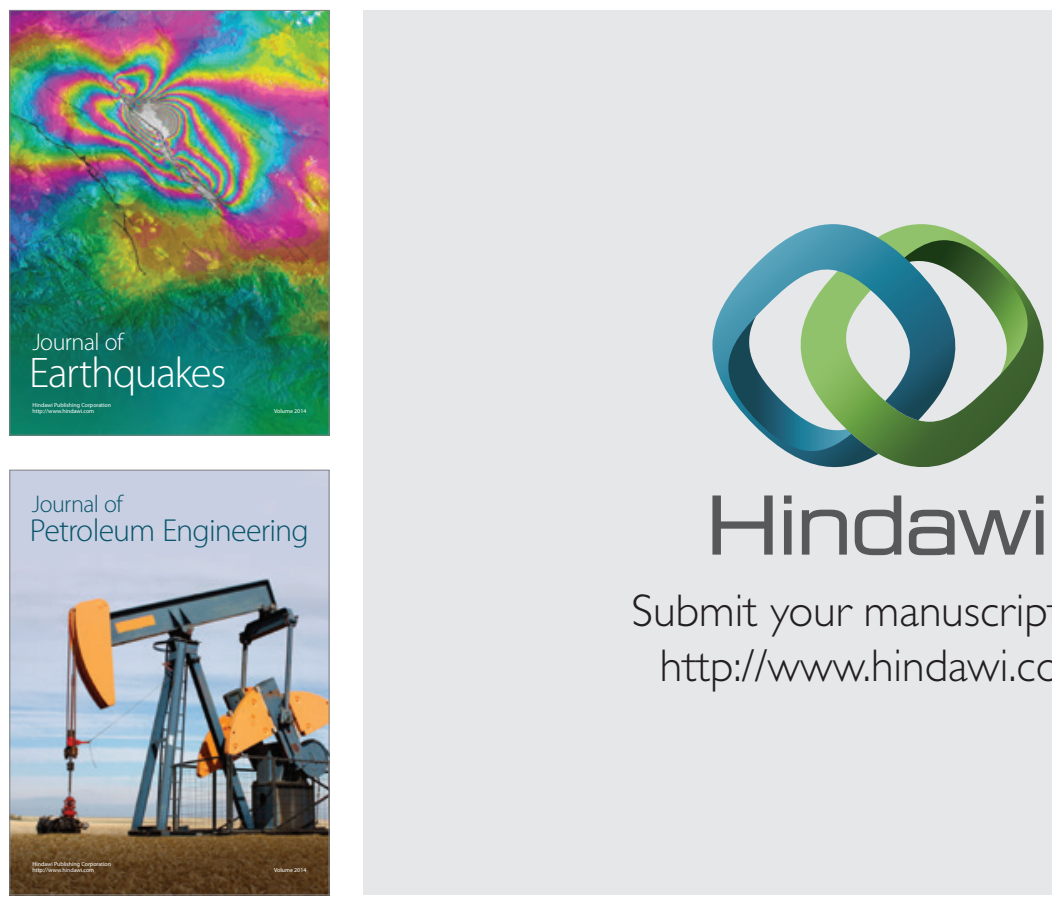

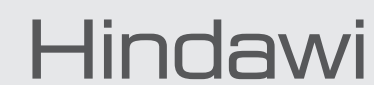

Submit your manuscripts at

http://www.hindawi.com
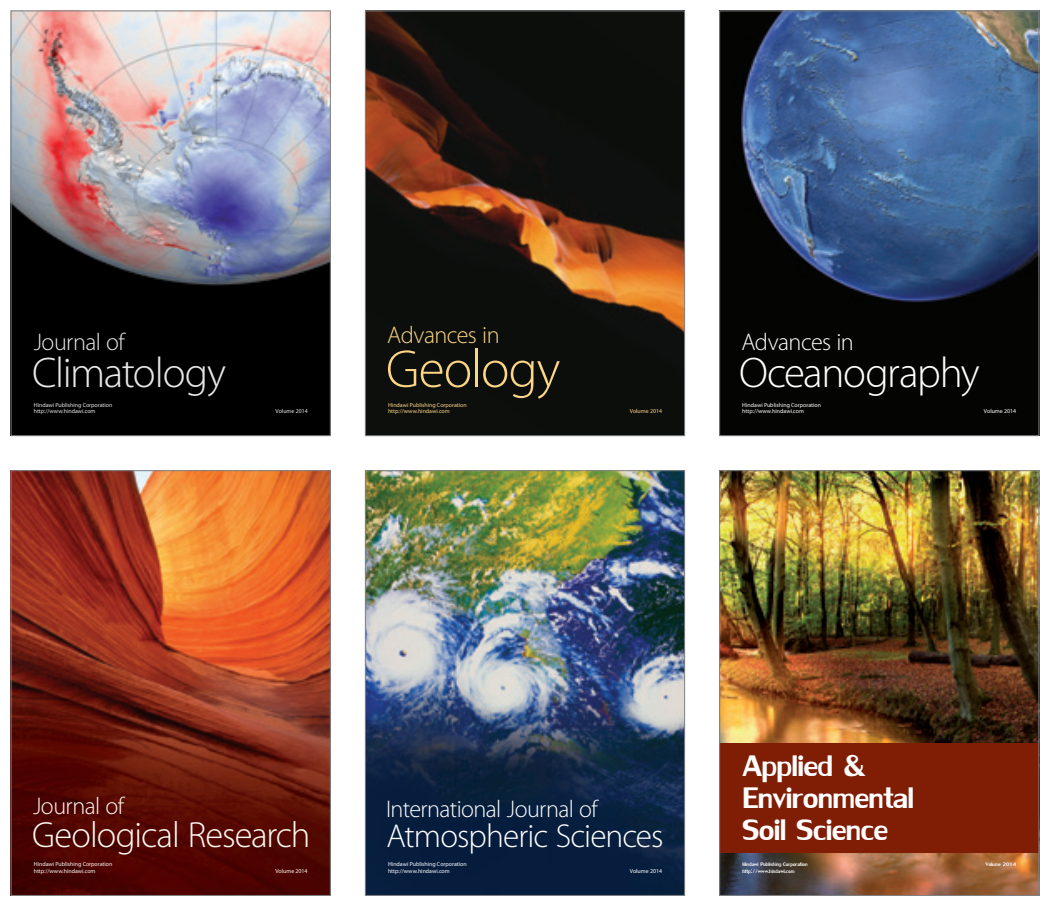
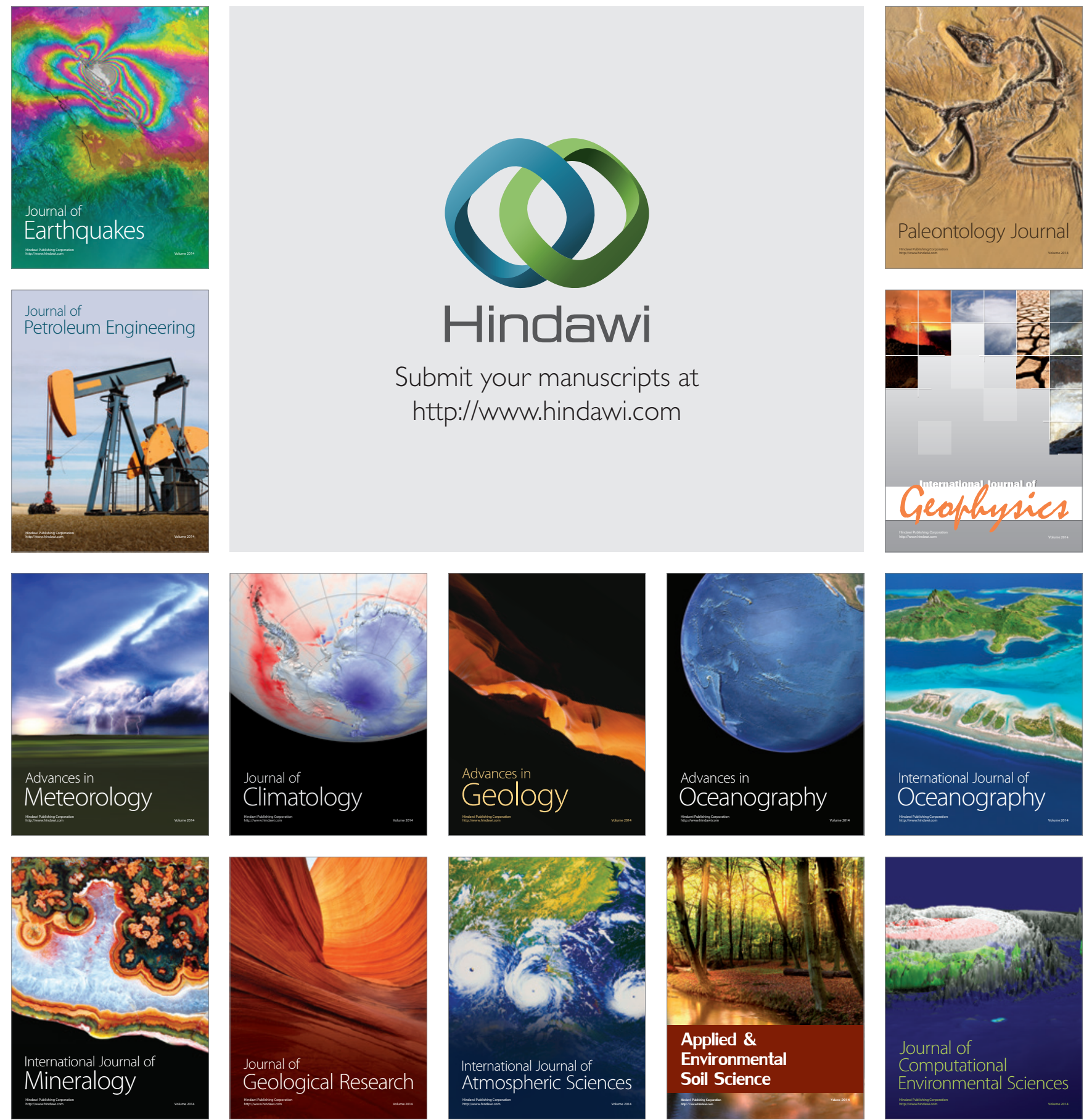